\title{
The Role of the Central Amygdala in Alcohol Dependence
}

\author{
Marisa Roberto, Dean Kirson, and Sophia Khom \\ Departments of Molecular Medicine and Neuroscience, The Scripps Research Institute, La Jolla, \\ California 92037, USA \\ Correspondence: mroberto@scripps.edu
}

\begin{abstract}
Alcohol dependence is a chronically relapsing disorder characterized by compulsive drugseeking and drug-taking, loss of control in limiting intake, and the emergence of a withdrawal syndrome in the absence of the drug. Accumulating evidence suggests an important role for synaptic transmission in the central nucleus of the amygdala (CeA) in mediating alcoholrelated behaviors and neuroadaptive mechanisms associated with alcohol dependence. Acute alcohol facilitates $\gamma$-aminobutyric acid (GABA)ergic transmission in the CeA via both pre- and postsynaptic mechanisms, and chronic alcohol increases baseline GABAergic transmission. Acute alcohol inhibits glutamatergic transmission via effects at $N$-methyl-D-aspartate (NMDA) and $\alpha$-amino-3-hydroxy-5-methyl-4-isoxazolepropionic acid (AMPA) receptors in the CeA, whereas chronic alcohol up-regulates NMDA receptor (NMDAR)-mediated transmission. Pro- (e.g., corticotropin-releasing factor [CRF]) and antistress (e.g., nociceptin/orphanin FQ, oxytocin) neuropeptides affect alcohol- and anxiety-related behaviors, and also alter the alcohol-induced effects on CeA neurotransmission. Alcohol dependence produces plasticity in these neuropeptide systems, reflecting a recruitment of those systems during the transition to alcohol dependence.
\end{abstract}

\begin{abstract}
lcohol use disorder (AUD) is a global health Aproblem. Alcoholism (i.e., dependence on alcohol) is a complex chronically relapsing disorder characterized by persistent alcoholseeking and alcohol-taking behaviors, loss of control in limiting intake (in terms of amount of drug per bout and number of drug-taking bouts), and the emergence of a withdrawal syndrome in the absence of the drug that includes, but is not limited to, dysphoria, sleep disturbances, disruption of autonomic processes, and increases in anxiety and irritability (ICD-10 and DSM-V). Preoccupation/anticipation, binge/in-
\end{abstract}

toxication, and withdrawal/negative affect are three stages conceptualized as feeding into one another, becoming more intense over time, and ultimately leading to the pathological state known as addiction/dependence (Wise and Koob 2014).

Decades of research have shaped the current view that excessive alcohol consumption is largely mediated by an organism's past experience with alcohol (e.g., intake pattern and frequency), and is driven by emotional disturbances rather than physical disturbances associated with alcohol withdrawal and abstinence

Editors: R. Christopher Pierce, Ellen M. Unterwald, and Paul J. Kenny

Additional Perspectives on Addiction available at www.perspectivesinmedicine.org

Copyright (C) 2021 Cold Spring Harbor Laboratory Press; all rights reserved; doi: 10.1101/cshperspect.a039339

Cite this article as Cold Spring Harb Perspect Med 2021;11:a039339 
M. Roberto et al.

(Koob 2003; Heilig et al. 2010). Importantly, the progression of alcohol addiction involves alterations in normal brain circuitry that result in long-lasting drug-induced neuroadaptations. The central nucleus of the amygdala $(\mathrm{CeA})$ is a brain region implicated in anxiety, stress-related disorders, and the reinforcing effects of alcohol and other drugs of abuse. Despite the critical role of the CeA in such negative affective alcohol responses, the neuronal circuitry underlying these behavioral stages is still not well understood. This review will focus on neurotransmission in the central amygdala and its role in driving the negative state of the withdrawal phase of alcohol addiction. Throughout this review, acute alcohol (ethanol) exposure refers to in vitro application of alcohol onto the slice preparation, whereas chronic alcohol exposure refers to long duration (at least several weeks) of in vivo alcohol exposure.

\section{CENTRAL AMYGDALA IS A HUB FOR NEGATIVE EMOTIONAL CIRCUITRY}

Chronic consumption of large quantities of drugs, including alcohol, promotes a transition from casual drug use to drug dependence that is defined in part by down-regulation of dopamine signaling in the mesocorticolimbic reward system, hyperactivity of glutamate signaling, and dysregulation of brain stress systems (Koob and Zorrilla 2010; Koob and Volkow 2016). Chronic alcohol effects on brain stress systems can refer to either alcohol-induced changes in neuroendocrine function (i.e., hypothalamic-pituitaryadrenal [HPA] axis) (Kiefer and Wiedemann 2004; Clarke et al. 2008) or the recruitment of extrahypothalamic brain stress systems such as the amygdala (Koob and Simon 2009; Koob 2016; Koob and Mason 2016). This review details the effects of acute and chronic alcohol on synaptic transmission and plasticity in the CeA and neighboring regions, and the role of these regions in mediating alcohol-related behaviors. We will review the literature on peptidergic modulation of inhibitory and excitatory transmission in the central (and extended) amygdala, because these peptides share a common cellular target and interact with each other and alcohol and thus represent novel therapeutic targets.
Many of the long-term emotional disturbances associated with alcohol abuse and dependence are attributed to neurotransmission within a conceptual macrostructure in the basal forebrain called the "extended amygdala" (Koob 2008). The major constituents of the extended amygdala are the CeA, the shell of the nucleus accumbens (NAc), and the lateral portion of the bed nucleus of the stria terminalis (BNST) (Heimer 1991). These brain structures share similar cytomorphology, a high degree of interconnectivity, and overlapping afferents from limbic cortices, hippocampus, and basolateral amygdala (BLA). The outputs of the extended amygdala project largely to effector regions, including lateral hypothalamus and various brainstem regions, that produce behaviors related to fear and anxiety (Davis et al. 2010).

The role of the extended amygdala in fear and anxiety has been previously described in detail (Ciocchi et al. 2010; Davis et al. 2010; Tye et al. 2011; Roberto et al. 2012). The CeA and the BNST are integral in mediating fear and anxiety responses. The BLA receives significant sensory input from the thalamus and cortex, sends prominent glutamatergic projections to the CeA and BNST, and is integral in both conditioning (Phelps and LeDoux 2005) and extinction (Quirk and Mueller 2008) processes. The CeA is composed mostly of $\gamma$-aminobutyric acid (GABA)ergic projection neurons and interneurons (Sun and Cassell 1993; Veinante and Freund-Mercier 1998), and the BNST is a major target of CeA projection neurons (Krettek and Price 1978; Weller and Smith 1982; Sun and Cassell 1993; Veinante and Freund-Mercier 1998). Of major relevance for this review, connections between CeA and BNST often contain neuropeptide cotransmitters (Penzo et al. 2014; Pomrenze et al. 2015). For example, the CeA is a major source of corticotropin-releasing factor (CRF) in the BNST (Sakanaka et al. 1986). Therefore, the CeA is uniquely situated to convert sensory information into behavioral and physiological responses, and this is particularly true for stress- and alcohol-related stimuli.

Neuropeptides in the CeA are important for producing the negative affective state observed during withdrawal from drugs, including alco- 
hol (Koob 2008; Gilpin and Roberto 2012). Here we will describe alcohol-induced neuroadaptations in select neuropeptidergic systems (CRF, nociceptin/orphanin FQ [nociceptin], oxytocin), largely in the context of the CeA. It is becoming increasingly evident that these peptides interact in complex ways in the CeA to modulate GABAergic inhibitory and glutamatergic excitatory transmission, and that dysregulation of these peptide systems by alcohol alters the way in which they modulate CeA activity. Conceptually, these neuropeptides have been divided into prostress peptides and antistress peptides, which, respectively, promote and rescue negative affective disturbances during drug abstinence following heavy drug use. Prostress peptides include CRF, dynorphin, orexin, and vasopressin, whereas antistress peptides include neuropeptide Y (NPY), enkephalin, oxytocin, and nociceptin; however, because of space limitations, we will discuss only a select few of these peptides.

\section{AMYGDALAR INHIBITORY GABAergic SYSTEM AND ALCOHOL}

GABA, the major inhibitory transmitter in the brain, acts on two classes of GABA receptors: $\mathrm{GABA}_{\mathrm{A}}$ (which includes $\mathrm{GABA}_{\mathrm{A}}$-rho subclass, formerly $\mathrm{GABA}_{\mathrm{C}}$ ) and $\mathrm{GABA}_{\mathrm{B}} \cdot \mathrm{GABA}_{\mathrm{A}}$ receptors are ligand-gated ion channels, whereas $\mathrm{GABA}_{\mathrm{B}}$ receptors are G-protein-coupled receptors (GPCRs). There is considerable evidence that GABAergic transmission mediates some aspects of alcohol-drinking behavior, but there is ambiguity in the literature with respect to the directions of these effects. Early studies showed that systemic administration of $\mathrm{GABA}_{\mathrm{A}}$ agonists increased voluntary alcohol drinking, whereas $\mathrm{GABA}_{\mathrm{A}}$ antagonists and benzodiazepine inverse agonists reduced alcohol intake (Boyle et al. 1993; Rassnick et al. 1993). Infusion of both $\mathrm{GABA}_{\mathrm{A}}$ agonists and antagonists into the NAc suppressed alcohol drinking by nondependent rats (Hodge et al. 1995). Systemic administration of a $\mathrm{GABA}_{\mathrm{B}}$ agonist suppressed alcohol drinking in all rats, but alcohol-dependent rats were more sensitive to this effect, suggesting an up-regulation of $\mathrm{GABA}_{\mathrm{B}}$ function (Walker and
Koob 2007). Other studies highlight a role for GABA circuitry in alcohol-drinking behavior, particularly in regions implicated in the negative reinforcing properties of the drug (i.e., extended amygdala). Hyytiä and Koob (1995) found that injection of $\mathrm{GABA}_{\mathrm{A}}$ antagonists in the three major regions of the extended amygdala suppressed alcohol drinking by nondependent rats, but this effect was most potent and selective for alcohol when infused into the $\mathrm{CeA}$. Another study showed that antagonism of $\mathrm{GABA}_{\mathrm{A}}$ in the BNST reversed decreases in alcohol drinking elicited by a $\mathrm{D}_{2}$ dopamine receptor antagonist infused into the ventral tegmental area (VTA) of alcohol-preferring (P) rats (Eiler and June 2007). Interestingly, infusion of a $\mathrm{GABA}_{\mathrm{A}}$ agonist directly into the amygdala suppresses drinking by alcohol-dependent rats without affecting intake by nondependent controls (Roberts et al. 1996). Although there are considerable methodological differences between these studies, they suggest that (1) chronic alcohol produces neuroadaptations in GABAergic neurotransmission and changes sensitivity to GABAergic compounds, (2) GABAergic neurotransmission regulates alcohol drinking, and (3) in the case of excessive alcohol consumption by alcohol-dependent rats, the CeA is a strong candidate region for localization of these effects.

\section{ACUTE ALCOHOL AUGMENTS INHIBITORY GABAergic TRANSMISSION IN THE CeA}

$\mathrm{GABA}_{\mathrm{A}}$ receptors mediate two distinct forms of inhibitory transmission: synaptic $\mathrm{GABA}_{\mathrm{A}}$ receptors mediating phasic inhibition and a tonic inhibition stemming from the activation of extrasynaptically located $\mathrm{GABA}_{\mathrm{A}}$ receptors by low concentrations of ambient GABA (Belelli et al. 2009; Hines et al. 2012). In heterologous expression systems, alcohol (1-100 mM) selectively enhances the function of distinct $\mathrm{GABA}_{\mathrm{A}}$ receptor subtypes (Harris et al. 2008; Sauguet et al. 2013; Wallner et al. 2014) but such findings have been inconsistent across laboratories (for reviews, see Aguayo et al. 2002; Lovinger and Homanics 2007).

The effects of acute alcohol on $\mathrm{GABA}_{\mathrm{A}}$ function have also been extensively studied with in 
M. Roberto et al.

vitro brain slice preparations, an approach that allows multiple methods for detecting changes in presynaptic transmitter release (for reviews, see Criswell and Breese 2005; Siggins et al. 2005; Weiner and Valenzuela 2006; Lovinger and Roberto 2013). Alcohol increases GABAergic synaptic transmission in the CeA (Roberto et al. 2003) and BLA (Zhu and Lovinger 2006) via increased presynaptic GABA release. Specifically, alcohol augments evoked inhibitory postsynaptic currents (IPSCs), decreases paired-pulse facilitation (PPF) of evoked IPSCs, and increases the frequency of miniature IPSCs (mIPSCs) (i.e., in tetrodotoxin [TTX] to eliminate action potential firing) in most CeA neurons, suggesting that alcohol increases vesicular GABA release (Roberto et al. 2003; Varodayan et al. 2017b,c).

Although the molecular mechanism(s) for alcohol effects have yet to be fully identified, we demonstrated that activation of adenylyl cyclase (AC), protein kinase C (PKC), and/or voltage-gated calcium channels are critical to the effects of acute alcohol on CeA $\mathrm{GABA}_{\mathrm{A}}$ mediated transmission (Bajo et al. 2008; Cruz et al. 2011; Varodayan et al. 2017b,c). Specifically, in CeA slices of mice lacking PKCE or when pretreated with a PKCE antagonist, the ability of acute alcohol to augment IPSCs is impaired (Bajo et al. 2008), suggesting that PKCE facilitates alcohol-elicited vesicular GABA release. Notably, basal GABA release is greater in the $\mathrm{CeA}$ of $\mathrm{PKC} \varepsilon$ knockout than wild-type mice, suggesting that in wild-type neurons, $\mathrm{PKC} \varepsilon$ limits spontaneous GABA release. Therefore, $\mathrm{PKC} \varepsilon$ serves at least two roles in the CeA: (1) limiting baseline GABA release, and (2) facilitating alcohol-stimulated release of GABA.

CeA neurons comprise three main cell types: (1) low-threshold bursting (LTB) characterized by one or two action potentials elicited by depolarizing current steps and after-hyperpolarization action potentials, (2) late spiking (LS) neurons exhibiting delayed action potentials elicited by depolarizing current steps, and (3) regular spiking (RS) neurons displaying consistent action potentials in response to depolarizing current steps (Dumont et al. 2002; Chieng et al. 2006). We found that acute alcohol increases spontaneous action-potential firing of
LTB neurons, decreases firing of LS neurons, and has mixed effects on RS neurons, suggesting divergent cell-type-specific effects of alcohol on the excitability of rat CeA neurons. Interestingly, LTB and some RS neurons possess a persistently active tonic conductance, mediated by $\alpha 1$ subunit containing $\mathrm{GABA}_{\mathrm{A}}$ receptors, which is insensitive to the effects of acute ethanol. In contrast, LS and a separate group of RS neurons do not possess an ongoing tonic conductance, but do display the potential for a tonic conductance, which is mediated by $\delta$-subunit containing $\mathrm{GABA}_{\mathrm{A}}$ receptors, and can be stimulated by acute ethanol or by elevating ambient GABA concentrations (Herman and Roberto 2016).

The ability of alcohol to facilitate GABA transmission may be limited by GABA feedback onto presynaptic $\mathrm{GABA}_{\mathrm{B}}$ (Wan et al. 1996; Ariwodola and Weiner 2004). For example, acute alcohol facilitates GABAergic transmission in the hippocampus (Wu and Saggau 1994; Wan et al. 1996; Ariwodola and Weiner 2004) and NAc (Nie et al. 2000) only if $\mathrm{GABA}_{B}$ receptors are blocked. However, in the $\mathrm{CeA}, \mathrm{GABA}_{\mathrm{B}}$ receptor blockade is not required for the enhancement of inhibitory postsynaptic potentials (IPSPs) by acute alcohol nor does it potentiate this effect (Roberto et al. 2003). Thus, the involvement of $\mathrm{GABA}_{\mathrm{B}}$ receptors in alcohol-induced GABA release may depend on the presence of presynaptic $\mathrm{GABA}_{\mathrm{B}}$ receptors in certain brain regions (Ariwodola and Weiner 2004; Breese et al. 2005).

\section{CHRONIC ALCOHOL EFFECTS ON GABAergic TRANSMISSION IN THE CeA}

Our in vitro electrophysiological results show that chronic alcohol exposure augments CeA GABA release (Roberto et al. 2004a). Alcoholdependent rats exhibit larger baseline-evoked $\mathrm{CeA} \mathrm{GABA}_{\mathrm{A}}$-mediated IPSP/C amplitudes, smaller baseline PPF of evoked IPSCs, and higher baseline frequency of mIPSCs compared to alcohol-naive rats. In vivo, microdialysis studies also indicate a large increase of baseline dialysate GABA concentrations in the CeA of alcoholdependent rats relative to naive controls, as well as lack of tolerance for acute alcohol-induced 
increases in dialysate GABA levels (Roberto et al. 2004a), strongly supporting the hypothesis that both acute and chronic alcohol alter presynaptic elements of CeA GABAergic synapses. Elevated $\mathrm{GABA}_{\mathrm{A}}$ receptor-mediated signaling in the CeA following chronic alcohol exposure emerges to be a common characteristic in alcohol dependence across species including mice (Herman et al. 2016), nonhuman primates (rhesus monkeys with a history of chronic ethanol self-administration and repeated abstinence) (Jimenez et al. 2019), and P rats (Herman et al. 2013b). For the latter, elevated GABA signaling was attributed to decreased CeA GABA transporter GAT-3 levels, indicative of impaired synaptic GABA clearance. Importantly, GAT-3 expression was also selectively decreased in the CeA of alcohol-dependent patients, suggesting a potential shared molecular mechanism for elevated $\mathrm{CeA}$ GABA transmission across species (Augier et al. 2018).

In chronically alcohol-exposed rats, acute alcohol augments CeA IPSCs, decreases PPF of IPSCs, and increases mIPSC frequency similarly in alcohol-dependent and alcohol-naive rats, suggesting a lack of tolerance for these acute effects of alcohol (Roberto et al. 2004a; Varodayan et al. 2017b). However, chronic intermittent ethanol (CIE) exposure leads to a loss of tonic conductance in rat LTB/RS neurons, likely leading to a disinhibition of this specific neuronal population, which leads to increased intra-CeA GABA release in dependent rats as compared to naive controls. Conversely, the emergence of an ongoing tonic conductance in LS/RS neurons following chronic intermittent alcohol exposure might blunt output function from these neurons. Given that tonic inhibition-a fine-tuned inhibitory control of neuronal activity-is a critical regulator of overall network activity (Semyanov et al. 2004; Brickley and Mody 2012), and dysfunctional $\mathrm{GABA}_{\mathrm{A}}$ receptor-mediated tonic signaling is associated with a number of neurological disorders (Hines et al. 2012), the loss of selective inhibition of these neurons following chronic alcohol could provide one potential mechanism by which chronic alcohol alters CeA output and contributes to behaviors associated with alcohol depen- dence (Herman and Roberto 2016). In nonhuman primates, acute ethanol also significantly increased spontaneous IPSC (sIPSC) frequency in controls, but not in abstinent drinkers, suggesting a tolerance to ethanol-induced GABA release in abstinent rhesus monkeys with a history of chronic ethanol self-administration and repeated abstinence (Jimenez et al. 2019).

Future studies will determine the exact molecular mechanisms responsible for chronic alcohol-induced adaptations in CeA neurons and their behavioral implications in alcoholdependent and/or alcohol-withdrawn organisms. These ongoing studies may elucidate the mechanism(s) underlying reductions in alcohol withdrawal hyperexcitability produced by GABA mimetic drugs (Ticku and Burch 1980; McCown et al. 1985; Breese et al. 2006; Roberto et al. 2008), and could impact treatment of pathological alcohol-drinking behaviors.

Chronic alcohol exposure produces tolerance to many behavioral effects of the drug, including the anxiolytic, sedative, ataxic, and positive reinforcing effects (Kumar et al. 2004, 2009). Chronic alcohol also produces physical and motivational dependence, and alcohol withdrawal is associated with increased neuronal excitability in several brain regions (but not $\mathrm{CeA}$ ) (Kliethermes 2005; Weiner and Valenzuela 2006). Chronic alcohol effects may reflect, in part, compensatory adaptations to the facilitatory effects of alcohol on GABAergic synapses (Siggins et al. 2005; Weiner and Valenzuela 2006). We showed that evoked IPSCs in CeA slices from alcohol-dependent rats are significantly larger than those from naive controls (Roberto et al. 2004a). Some CeA neurons from alcohol-dependent rats also exhibit increased mIPSC amplitudes relative to naive rats, suggesting a postsynaptic effect of chronic alcohol (Roberto et al. 2004a). Substantial evidence suggests that alcohol-induced behavioral and neural adaptations are attributable to changes in $\mathrm{GABA}_{\mathrm{A}}$ subunit composition rather than changes in the number of $\mathrm{GABA}_{\mathrm{A}}$ (Morrow et al. 1992; Eckardt et al. 1998; Grobin et al. 1998; Papadeas et al. 2001; Kumar et al. 2004, 2009; Lee et al. 2014).

In alcohol-naive rats, a $\mathrm{GABA}_{\mathrm{B}}$ antagonist increased the amplitude of evoked IPSCs and 
M. Roberto et al.

decreased PPF of IPSCs in the CeA, suggesting tonic activation of presynaptic $\mathrm{GABA}_{\mathrm{B}}$ (Roberto et al. 2008). Conversely, a $\mathrm{GABA}_{\mathrm{B}}$ agonist markedly depressed evoked IPSC amplitudes and increased PPF of IPSCs in the CeA of alcoholnaive rats, indicating decreased presynaptic GABA release. These effects of $\mathrm{GABA}_{\mathrm{B}}$ agonists and antagonists were absent or greatly attenuated in the CeA of alcohol-dependent rats, suggesting chronic alcohol-induced down-regulation of the $\mathrm{GABA}_{\mathrm{B}}$ system, which may explain the increased GABAergic tone observed in the CeA of dependent rats (Roberto et al. 2008). These alcohol-dependence-induced neuroadaptations of the $\mathrm{GABA}_{\mathrm{B}}$ system also may account for chronic alcohol-induced changes in gabapentin effects on inhibitory transmission in the CeA. Gabapentin, a structural analog of GABA (Sills 2006), increases the amplitudes of evoked IPSCs in CeA neurons from nondependent rats (an effect blocked by a $\mathrm{GABA}_{\mathrm{B}}$ antagonist), but decreases IPSC amplitudes in the $\mathrm{CeA}$ of alcohol-dependent rats. Notably, gabapentin infused into the CeA reverses dependence-induced increases in operant alcohol responding but tends to increase alcohol drinking by nondependent rats (Roberto et al. 2008).

\section{ALCOHOL AND GLUTAMATERGIC TRANSMISSION IN THE AMYGDALA}

Glutamate, the major excitatory neurotransmitter, has long been implicated in the reinforcing actions of alcohol. Glutamate receptors include three major classes of ionotropic (iGluRs), with varying ratios of selectivity for $\mathrm{Na}^{+}, \mathrm{K}^{+}$, and $\mathrm{Ca}^{2+}$. The iGluRs include $\alpha$-amino-3-hydroxy5-methyl-4-isoxazolepropionic acid (AMPA) receptors (AMPARs), N-methyl-D-aspartic acid (NMDA) receptors (NMDARs), and kainate receptors (KARs). Additionally, there are various subclasses of metabotropic GLuRs (mGluRs) that are GPCRs.

In contrast to its potentiating effects on GABA systems, alcohol generally inhibits glutamate neurotransmission in the brain (Lovinger and Roberto 2013). Dysregulation of glutamate systems may contribute to hyperexcitability and craving associated with alcohol withdrawal (Pul- virenti and Diana 2001). In the CeA of P rats, long-term consumption of high quantities of alcohol increases expression of mGluRs, NMDAR subunits, and a scaffolding protein regulating expression of these receptors in the cell membrane (Obara et al. 2009). Group II mGluRs also may block stress- and cue-induced reinstatement of alcohol-seeking behavior via neuronal activation in the CeA or BNST (Zhao et al. 2006). Excitatory transmission in the CeA may also mediate some of the aversive aspects of withdrawal from abused drugs (e.g., morphine [Watanabe et al. 2002]).

Acamprosate, approved for treatment of alcoholic patients, modulates glutamate transmission via actions at NMDARs and/or mGluRs (Berton et al. 1998; Blednov and Harris 2008; Mann et al. 2008). Notably, acamprosate dampens the increased glutamate levels in abstinent alcoholics measured by magnetic resonance spectroscopy (Umhau et al. 2010), and reduces excessive alcohol drinking in alcoholics, presumably by reducing craving and negative affect (for review, see Littleton 2007). AMPARs may be important in regulating relapse-like behaviors without playing a central role in alcohol consumption per se (Sanchis-Segura et al. 2006).

\section{ACUTE ALCOHOL EFFECTS ON GLUTAMATERGIC TRANSMISSION IN THE CeA}

We demonstrated that acute alcohol (5-66 mM) decreases excitatory postsynaptic potentials (EPSPs) and currents (EPSCs) in the CeA, and that these effects are mediated by both NMDAR and non-NMDAR mechanisms (Roberto et al. 2004b). In contrast to alcohol effects on GABA release, the majority of studies indicate that acute alcohol either has no effect on or inhibits glutamate release (for review, see Roberto et al. 2005) and inhibits NMDAR, AMPAR, and KAR function in some neuron types (for review, see Lovinger and Roberto 2013).

\section{CHRONIC ALCOHOL EFFECTS ON EXCITATORY TRANSMISSION IN THE CeA}

Chronic alcohol produces neuroadaptations in glutamatergic synaptic transmission. For 
example, acute alcohol decreases NMDARmediated EPSPs and EPSCs in the CeA of alcohol-dependent rats more than in alcoholnaive controls. With local NMDA application, acute alcohol inhibits NMDA currents more in slices from alcohol-dependent rats, suggesting that alcohol dependence sensitizes NMDARs to alcohol (Roberto et al. 2004b, 2006). NMDARs containing the NR2B subunit are most sensitive to chronic alcohol exposure (Floyd et al. 2003; Carpenter-Hyland et al. 2004; Roberto et al. 2004b; Kash et al. 2009). Chronic alcohol increases NR2B messenger RNA (mRNA) and/or protein levels (Roberto et al. 2006; Kash et al. 2009) in the CeA and BNST, but not in other brain regions (Cebere et al. 1999; Floyd et al. 2003; Läck et al. 2005). It is not yet clear whether increased NR2B subunit expression is the major driving force behind alcohol-induced increases in NMDAR function, or what molecular mechanisms underlie these subunit changes.

Chronic alcohol has also been associated with functional up-regulation of $\mathrm{mGluR}_{2 / 3}$ receptor signaling in the CeA and BNST (Kufahl et al. 2011). Furthermore, chronic ethanol selfadministration (alcohol-deprivation model) also increased spontaneous EPSC (sEPSC) rise times indicative of compromised CeA glutamatergic receptor function (Suárez et al. 2019). Additionally, we found that CIE treatment did not alter evoked CeA glutamate but decreased both spontaneous vesicular glutamate (miniature EPSCs [mEPSCs]) release and postsynaptic glutamate receptor function at $\mathrm{CeA}$ synapses $(\mathrm{Va}-$ rodayan et al. 2017a).

Microdialysis experiments in the amygdala revealed increased glutamate release following chronic alcohol exposure (at 2-8 h withdrawal in the CeA [Roberto et al. 2004b]; at $24 \mathrm{~h}$ withdrawal in BLA [Läck et al. 2007]). Our laboratory found that chronic alcohol exposure unmasks the ability of acute alcohol to increase presynaptic glutamate release in the CeA (Roberto et al. 2004b), an effect that persisted 2 weeks into abstinence (Roberto et al. 2006).

Collectively, these data suggest that multiple factors contribute to increased extracellular glutamate levels and altered glutamatergic trans- mission following chronic alcohol exposure and withdrawal.

\section{CENTRAL AMYGDALA NEUROPEPTIDES AND ALCOHOL DEPENDENCE}

Neuropeptidergic systems play key roles in regulating anxiety-like and alcohol-drinking behaviors in subjects that are either alcohol-dependent, genetically vulnerable to developing excessive drinking (e.g., via selective breeding), and genetically predisposed to anxiety, as well as repeatedly cycled through periods of alcohol withdrawal. The CeA contains high concentrations of prostress (e.g., CRF, orexin, vasopressin, etc.) and antistress (e.g., nociceptin, oxytocin, enkephalin, NPY, etc.) neuropeptides, and many effects of these neuropeptides on anxiety- and alcohol-related behaviors have been localized to the CeA. Because of space limitations, we review here the actions of a few neuropeptides on inhibitory transmission in the CeA, with a focus on the CRF system that is heavily recruited during the transition from casual alcohol use to dependence (Koob and Zorrilla 2010).

The CeA is the major output center of the amygdala, and about $95 \%$ of CeA neurons are medium spiny GABAergic neurons (McDonald 1982). The CeA is not a homogeneous neuroanatomical structure, and can be subdivided into lateral $(\mathrm{CeL})$ and medial $(\mathrm{CeM})$ aspects that differ in neuropeptide content, origin of afferents, and target sites of efferent projections (for reviews, see Sun et al. 1991; Petrovich et al. 1996; Pitkänen et al. 2000; Dong et al. 2001; Ciocchi et al. 2010; Davis et al. 2010; Haubensak et al. 2010; McCullough et al. 2016). The CeL contains a much higher density of neuropeptides (e.g., dynorphin, CRF [Veening et al. 1984; Cassell et al. 1986; Shimada et al. 1989; Pomrenze et al. 2015; Wolfe et al. 2019]) than the CeM, receives input from cortex and thalamus, and sends inhibitory inputs to the CeM, thereby gating the output activity of the CeA, but also to more distant brain regions such as the periaqueductal gray and paraventricular nucleus (PVN) of the thalamus (Penzo et al. 2014). By contrast, the 
M. Roberto et al.

CeM receives prominent inputs from other amygdaloid nuclei (especially glutamatergic afferents from BLA) and sends inhibitory projections to various effector regions (e.g., hypothalamus, periaqueductal gray, locus coeruleus, and pedunculopontine tegmental nucleus) (Krettek and Price 1978; Pitkänen and Amaral 1994). Both the CeL and CeM project to the BNST (Sun et al. 1991).

\section{CRF AND ALCOHOL-RELATED BEHAVIOR}

CRF plays a central role in arousal and hormonal, sympathetic, and behavioral responses to stress (Roberto et al. 2017). Dysregulation of the CRF system is implicated in numerous psychiatric disorders including anxiety, depression, addiction, posttraumatic stress disorder, and eating disorders (Menzaghi et al. 1994; Koob 2003, 2008; Valdez et al. 2003; Chu et al. 2007; Funk et al. 2007; Ciocchi et al. 2010; Tye et al. 2011; Bruijnzeel et al. 2012; Iemolo et al. 2013; Ji et al. 2013; Baiamonte et al. 2014). The CeA, BNST, and BLA contain abundant CRF neurons and their cognate CRF type 1 and $2\left(\mathrm{CRF}_{1}\right.$ and $\mathrm{CRF}_{2}$ ) receptors (De Souza et al. 1984; Sakanaka et al. 1986; Roberto et al. 2017).

Pharmacological and transgenic studies support that brain and pituitary $\mathrm{CRF}_{1}$ receptors mediate endocrine, behavioral, and autonomic responses to stress (Koob and Heinrichs 1999; Heinrichs and Koob 2004; Zorrilla and Koob 2010; Zorrilla et al. 2013), and $\mathrm{CRF}_{2}$ receptor activation has been associated with decreased feeding (Spina et al. 1996; Pelleymounter et al. 2000; Fekete and Zorrilla 2007; Gilpin 2012; Roberto et al. 2017).

Hyperfunction of CRF systems in the CeA, BLA, and BNST produce increases in anxietylike behavior (Sajdyk et al. 1999; Rainnie et al. 2004; Lee et al. 2008). Extracellular CRF levels in the $\mathrm{CeA}$ are elevated following exposure to stress and development of alcohol dependence (Merlo Pich et al. 1995; Zorrilla et al. 2001), and alcohol withdrawal increases CRF synthesis and release in the CeA (Funk et al. 2006; Sommer et al. 2008; Roberto et al. 2010). Likewise, alcohol withdrawal increases extracellular CRF in the BNST (Olive et al. 2002), and these increases are normalized by alcohol consumption. In contrast, the effects of binge drinking on CeA CRF is dependent on the age at the time of alcohol exposure and may affect subsequent alcohol-related behaviors (Gilpin 2012). Following 2 weeks of binge-like alcohol intake, adolescent rats display decreases in CRF cell number in the CeA and no changes in BNST (Karanikas et al. 2013). In adult mice, one and six cycles of the drinking in the dark paradigm (DID) increases CeA CRF immunoreactivity, suggesting that the CRF system is recruited during early binge-like drinking episodes (Lowery-Gionta et al. 2012). Notably, the synaptic effects of CRF on CeA GABAergic transmission are reduced after repeated bouts of binge-like drinking (Lowery-Gionta et al. 2012).

$\mathrm{CRF}_{1}$ and $\mathrm{CRF}_{2}$ antagonists suppress dependence-induced increases in alcohol drinking during acute withdrawal and protracted abstinence (Valdez et al. 2002) and reverse increases in stress-induced anxiety during protracted abstinence (Valdez et al. 2003). CRF repeatedly administered into the CeA, BLA, or dorsal BNST exaggerates alcohol withdrawal-induced increases in anxiety-like behavior via $\mathrm{CRF}_{1} \mathrm{~s}$ (Huang et al. 2010). Conversely, antagonism of CRF receptors (CRFRs) in the CeA blunts the increases in anxiety-like behavior in rats during withdrawal from chronic high-dose alcohol exposure (Rassnick et al. 1993).

Many findings in animal models implicate $\mathrm{CRF}_{1}$ receptors specifically in these "dark side" actions of CRF (or other endogenous $\mathrm{CRF}_{1}$ agonists) to produce a negative emotional state. Specifically, $\mathrm{CRF}_{1}$ antagonists block the anxiogenic effects of many stressors (Arborelius et al. 2000; Zorrilla et al. 2014). CRF 1 antagonists also block increases in alcohol self-administration elicited by stressors and withdrawal (Hansson et al. 2006; Funk et al. 2007; Gehlert et al. 2007; Marinelli et al. 2007; Lowery et al. 2008). Chronic treatment with a $\mathrm{CRF}_{1}$ antagonist abolishes dependence-induced escalation of drinking in rats chronically exposed to high doses of alcohol (Roberto et al. 2010). Likewise: (1) stressors and alcohol withdrawal increase $\mathrm{CRF}_{1}$ expression in limbic brain regions (Aguilar-Valles et al. 2005; 
The Central Amygdala and Alcohol

Sommer et al. 2008; Eisenhardt et al. 2015); (2) rats bred for high alcohol preference show increased anxiety-like behavior and $\mathrm{CRF}_{1}$ levels (Ciccocioppo et al. 2006); and (3) $\mathrm{CRF}_{1}$ knockout mice exhibit decreased anxiety-like behavior (Müller et al. 2003) and resistance to the ability of repeated forced swim stress to increase deprivation-induced ethyl alcohol $(\mathrm{EtOH})$ intake (Pastor et al. 2011). In addition, conditional brain-specific Crhr1 knockout mice (Molander et al. 2012) show reduced EtOH intake during withdrawal compared to their wild-type littermates. Notably, $\mathrm{CRF}_{1}$ antagonists also block the decreased brain reward function observed in animal models of withdrawal from nicotine, alcohol, or opioids, evident as increased current thresholds for intracranial self-stimulation behavior (Bruijnzeel et al. 2007, 2009, 2010).

CRF-binding protein (CRF-BP) binds CRF with equal or greater affinity than do CRFRs, limiting its bioavailability and serving as an endogenous negative regulator of CRF signaling (Potter et al. 1992; Behan et al. 1995; Ketchesin et al. 2016), and/or alternatively to chaperone/ complex with the peptide to provide a different signaling method. The distribution of the CRFBP overlaps partly with that of CRF, notably in the cortex and amygdala (Potter et al. 1992; Behan et al. 1995; Ketchesin et al. 2016), where terminals containing CRF-BP colocalize with CRF-positive cell bodies supporting their regulatory interaction (Westphal and Seasholtz 2006). Recently, the CRF-BP has been considered a potential target for its role in AUD (Haass-Koffler et al. 2016; Ketchesin et al. 2016), and its role in the escalation of alcohol drinking may involve its interaction with $\mathrm{CRF}_{2}$ (Albrechet-Souza et al. 2015; Quadros et al. 2016). In addition, gene variant studies in humans have revealed that the CRHBP rs 1875999 locus is associated with risk for both cocaine and heroin addiction in African-Americans (Levran et al. 2014a,b). Single-nucleotide polymorphisms (SNPs) in the CRHBP $(10 \mathrm{kD})$ fragment, rs10055255, rs10062367, and rs7728378 were each associated with increased risk of alcohol drinking and/or anxiety in patients with AUD (Haass-Koffler et al. 2016).

\section{CRF EFFECTS ON SYNAPTIC TRANSMISSION IN THE CeA}

CRF robustly increases GABAergic transmission in the CeA of rats (Roberto et al. 2010) and mice (Nie et al. 2004, 2009) mainly via activation of $\mathrm{CRF}_{1}$ s. Notably, $\mathrm{CRF}_{1}$ antagonists decrease presynaptic GABA release, suggesting tonic facilitation of GABA release by endogenous $\mathrm{CRF}$. $\mathrm{CRF}_{1}$ antagonists and $\mathrm{CRF}_{1}$ knockouts also block the alcohol-induced augmentation of GABAergic transmission in the CeA. Both CRF- and alcohol-induced facilitation of GABAergic transmission in the CeA require the $\mathrm{PKC} \varepsilon$ signaling pathway (Bajo et al. 2008). Alcohol-dependent rats show increased sensitivity to the effects of $\mathrm{CRF}$ and $\mathrm{CRF}_{1}$ antagonists on GABA release in the CeA, suggesting up-regulation of the CRF-CRF $\mathrm{C}_{1}$ system. These findings are further supported by increased CRF and $\mathrm{CRF}_{1}$ mRNA levels seen in the CeA of alcohol-dependent rats, and by reversal of dependence-induced elevations in amygdalar GABA dialysate by a $\mathrm{CRF}_{1}$ antagonist (Roberto et al. 2010). CRF also increases GABAergic transmission in the BNST, likely via actions at postsynaptic $\mathrm{CRF}_{1} \mathrm{~s}$ (Kash and Winder 2006; Francesconi et al. 2009).

Given the critical role of the $\mathrm{CRF} / \mathrm{CRF}_{1}$ system and the cellular heterogeneity in the CeA, we used a bacterial artificial chromosome (BAC) transgenic mouse line expressing the green fluorescent protein (GFP) under the Crhr1 promoter $\left(\mathrm{CRF}_{1}: \mathrm{GFP}\right)$ to readily identify neurons expressing $\mathrm{CRF}_{1}\left(\mathrm{CRF}_{1}{ }^{+}\right.$) (Justice et al. 2008; Herman et al. 2013a, 2016) to unveil unique molecular, morphological, and functional properties that distinguish $\mathrm{CeA} \mathrm{CRF}{ }_{1}{ }^{+}$neurons from their $\mathrm{CRF}_{1}$ nonexpressing $\left(\mathrm{CRF}_{1}{ }^{-}\right)$neighbors. We found that $\mathrm{CRF}_{1}{ }^{+}$neurons are mainly located in the CeM and exhibit an ongoing tonic GABAergic conductance driven by action potential-dependent GABA release. In contrast, $\mathrm{CRF}_{1}{ }^{-}$neurons do not display tonic inhibition (Herman et al. 2013a). We also reported functional adaptations to CIE exposure on phasic and tonic inhibition and cell firing in $\mathrm{CRF}_{1}{ }^{+}$ and $\mathrm{CRF}_{1}{ }^{-} \mathrm{CeA}$ neurons (Herman et al. 2016). Notably, ongoing tonic conductance in $\mathrm{CRF}_{1}{ }^{+}$ 
M. Roberto et al.

neurons in control mice was lost following CIE. In contrast, $\mathrm{LS} \mathrm{CRF}_{1}{ }^{-}$neurons showed a tonic conductance following CIE that was not observed in controls. We observed a loss of tonic currents and a significantly higher basal firing rate in $\mathrm{CRF}_{1}{ }^{+} \mathrm{CeA}$ neurons projecting to the BNST of CIE versus control mice.

Overall, our studies have yielded significant insight into cell-type-specific effects of acute and chronic alcohol in local and downstream CeA circuits revealing that CIE alters inhibitory control of $\mathrm{CeA} \mathrm{CRF}_{1}$ output neurons. More recently, we also assessed expression of subpopulation markers and neuropeptides, dendritic spine density and morphology, and glutamatergic transmission in the $\mathrm{CeA} \mathrm{CRF}_{1}{ }^{+}$versus $\mathrm{CRF}_{1}{ }^{-}$neurons (Wolfe et al. 2019). In brief, $\mathrm{CeA} \mathrm{CRF}_{1}{ }^{+}$neurons are GABAergic, but do not segregate with calbindin, calretinin, or $\mathrm{PKC} \delta$. Coexpression analysis using in situ hybridization revealed Crhrl had the highest coexpression with Penk and Sst and the least with Npy. Additionally, CeA $\mathrm{CRF}_{1}{ }^{+}$neurons do not display differences in mature spines and, accordingly, no difference in basal CeA glutamate transmission. Application of CRF increases overall glutamate release onto both $\mathrm{CRF}_{1}{ }^{+}$and $\mathrm{CRF}_{1}{ }^{-}$neurons but increases postsynaptic glutamate receptor functions selectively in $\mathrm{CRF}_{1}{ }^{+}$ neurons (Wolfe et al. 2019).

We also studied CIE-induced changes in the modulation of rat glutamatergic synapses by CRF (Varodayan et al. 2017a). We found that CRF (25-200 nM) also decreased CeA EPSPs evoked locally or by BLA stimulation, indicating that CRF similarly decreases glutamatergic responses. In contrast to the evoked data but in agreement with our recent work, CRF increased mEPSC frequency similarly in naive and CIE neurons, suggesting increased vesicular glutamate release (Varodayan et al. 2017a). Antagonism of $\mathrm{CRF}_{1} / \mathrm{CRF}_{2}$ and $\mathrm{CRF}_{1}$ alone decreased $\mathrm{mEPSC}$ frequency in naive CeA neurons, whereas antagonism of $\mathrm{CRF}_{2}$ increased it. Our studies also revealed that $\mathrm{CRF}_{2}$ receptors under basal conditions tonically inhibit glutamate release, as their blockade increased vesicular glutamate release. In contrast, $\mathrm{CRF}_{1}$ receptors tonically enhance glutamate release, in which $\mathrm{CRF}_{1}$ blockade decreased glutamate release. Accordingly, CRF did not significantly affect glutamate release in the presence of CRFR antagonists. In contrast, in the presence of the antagonist astressin-2B, CRF further enhanced glutamate release, suggesting that $\mathrm{CRF}_{2}$ receptors tonically inhibit glutamate, and $\mathrm{CRF}_{2}$ blockade resulted in a larger CRF-induced facilitation of glutamate release (Varodayan et al. 2017a). Thus, the CRFinduced facilitation of glutamate release is mediated by $\mathrm{CRF}_{1}$ receptors, but the mechanisms are complex and may involve both $\mathrm{CRF}_{1}$ and $\mathrm{CRF}_{2}$ receptors with opposite receptor subtype effects on glutamate release (Varodayan et al. 2017a).

\section{NOCICEPTIN/ORPHANIN FQ AND ALCOHOL-RELATED BEHAVIOR}

The neuropeptide nociceptin/orphanin FQ (N/ OFQ) (Meunier et al. 1995; Reinscheid et al. 1995; Meunier 1997) and its cognate receptor nociceptin opioid peptide (NOP) are widely expressed in the brain (Neal et al. 1999). Nociceptin is an opioid-like peptide that acts at NOP receptors, although it does not bind to opioid receptors and opioids do not bind to NOP receptors. Nociceptin is abundantly expressed in the CeA and BNST (Neal et al. 1999) and is described as a functional CRF antagonist (Ciccocioppo et al. 2003). Earlier studies showed that nociceptin and other NOP agonists have an anxiolytic-like profile in animal studies (Jenck et al. 1997, 2000), and nociceptin knockout mice show increased anxiety-like behavior (Koster et al. 1999) and are more sensitive to social stress (Ouagazzal et al. 2003). Numerous studies also reported that NOP activation significantly decreased drinking, alcohol-induced conditioned place preference, and decreased reinstatement evoked by stress or cues (Ciccocioppo et al. 1999, 2004, 2014a; Martin-Fardon et al. 2000; Kuzmin et al. 2003, 2007; Witkin et al. 2014; Toll et al. 2016).

Generally, rats bred for high alcohol intake show increased sensitivity to the suppressive effects of nociceptin on drinking and related behaviors (Economidou et al. 2008). Human alcoholics express decreased levels of mRNA for 
NOP in the CeA (Kuzmin et al. 2007), suggesting that the $\mathrm{CeA}$ is a critical site for a role of nociceptin in alcoholism.

Subsequent studies reported similar effects using NOP antagonists (Witkin et al. 2016; Ciccocioppo et al. 2019). For instance, the NOP antagonist LY2940094 decreased voluntary ethanol intake in alcohol-preferring and -nonpreferring rats (Rorick-Kehn et al. 2016). Moreover, NOP knockout rats self-administer significantly less alcohol than their wild-type counterpart, suggesting a facilitatory role of NOP receptors (Kallupi et al. 2017). Recent clinical data showed the translational potential of NOP modulation as LY2940094 was effective in reducing drinking in humans (Post et al. 2016). There is an ongoing debate on the mechanisms underlying similar effects using both NOP agonists and antagonists in decreasing the motivation for alcohol. One possible explanation is that NOP agonists may act through mechanisms involving desensitization of the system (Ciccocioppo et al. 2019).

\section{NOCICEPTIN AND SYNAPTIC TRANSMISSION IN THE CeA}

At the cellular level, nociceptin dose-dependently and reversibly reduced evoked and spontaneous $\mathrm{GABA}_{\mathrm{A}}$ receptor-mediated IPSCs in CeA (Roberto and Siggins 2006) via decreasing presynaptic GABA release. Notably, nociceptin both prevented (when applied before alcohol) and totally reversed (applied during alcohol) acute alcohol-induced increases in evoked IPSC amplitudes and mIPSC frequencies and decreases in PPF, thus preempting the usual alcohol-induced increase in GABA release in CeA. Further, the ability of nociceptin to decrease GABAergic transmission in CeA is augmented following alcohol dependence, suggesting that the nociceptin system in the CeA adapts during chronic alcohol exposure (Roberto and Siggins 2006).

We also found that the maximally effective and reversible concentration of nociceptin completely blocked the CRF-induced increase of IPSCs (Roberto et al. 2010), suggesting that nociceptin antagonized the effect of CRF (Cruz et al. 2012). We also reversed the sequence of drug application and applied CRF first followed by nociceptin-CRF coapplication. Nociceptin decreases the amplitude of IPSPs and completely blocks the CRF-induced increase in GABAergic transmission. Moreover, the NOP receptor antagonist $\left[\mathrm{Nphe}^{1}\right]$ nociceptin(1-13) $\mathrm{NH}_{2}$ blocked the nociceptin-induced diminution of IPSCs but not the CRF-induced augmentation of IPSCs, indicating that nociceptin modulates both ethanol and CRF effects through the NOP receptors. Nociceptin also blocked CRF-induced increases in GABAergic responses in CeA from ethanol-dependent rats (Cruz et al. 2012).

Using a multidisciplinary approach, we also explored the relationship between the nociceptin and CRF systems in response to acute restraint stress (Ciccocioppo et al. 2014a). We found a selective up-regulation of the nociceptin and down-regulation of the $\mathrm{CRF}_{1}$ receptor transcripts in the CeA and BLA after restraint. We evaluated the anxiety-like response in rats subjected to restraint stress and nonrestrained rats after nociceptin microinjection into the CeA (Ciccocioppo et al. 2014a). Notably, intra-CeA injections of nociceptin significantly and selectively reduced anxiety-like behavior in restrained rats in the elevated plus maze. Finally, we electrophysiologically explored functional interactions between CRF and nociceptin systems in the CeA. Acute application of CRF significantly increased GABAergic responses, and this enhancement was blocked by nociceptin (Ciccocioppo et al. 2014a). Importantly, in restraint stressed rats, baseline CeA GABAergic responses were elevated and nociceptin exerted a larger inhibition of GABA responses compared with nonrestrained rats. Application of the nociceptin antagonist revealed a functional recruitment of the nociceptin receptor after acute stress. These combined results demonstrate that acute stress and alcohol dependence increase nociceptin system function in the $\mathrm{CeA}$ and provide translational support for nociceptin as a "drugable" candidate system for medication development for the treatment of alcoholism (Ciccocioppo et al. 2014a). 
M. Roberto et al.

As a long-term goal in the context of these basic neurobiological mechanism studies, we seek to identify novel molecules, such as nociceptin agonists, which moderate alcoholism risk by acting at the cellular level in brain regions such as the amygdala that are associated with ethanol dependence. In collaboration with Mitsubishi Pharma (Osaka, Japan), we tested a novel nociceptin receptor agonist (MT-7716) in our in vitro CeA brain slice preparation (Kallupi et al. 2014) and in behavioral studies (Ciccocioppo et al. 2014b).

Previously, we reported that in the rat CeA, acute and chronic ethanol exposures significantly decrease glutamate transmission by both pre- and postsynaptic actions (Roberto et al. 2004b).

Nociceptin diminished basal-evoked compound glutamatergic EPSPs and sEPSCs and mEPSCs by mainly decreasing glutamate release in the CeA of naive rats (Kallupi et al. 2014). Notably, nociceptin blocked the inhibition induced by acute ethanol and ethanol blocked the nociceptin-induced inhibition of evoked glutamatergic responses in CeA neurons of naive rats. In neurons from ethanol-dependent rats, the nociceptin-induced inhibition of glutamatergic responses was not significantly different from that in naive rats. Application of $\left[\mathrm{Nphe}^{1}\right]$ Nociceptin(1-13) $\mathrm{NH}_{2}$ revealed tonic inhibitory activity of NOP on evoked CeA glutamatergic transmission only in alcohol-dependent rats. The antagonist also blocked nociceptin-induced decreases in glutamatergic responses but did not affect ethanol-induced decreases in evoked EPSP amplitude. Taken together, these studies implicate a potential role for the nociceptin system in regulating glutamatergic transmission and a complex interaction with ethanol at CeA glutamatergic synapses (Kallupi et al. 2014).

\section{OXYTOCIN AND ALCOHOL DRINKING}

The neuropeptide oxytocin is involved in many biological processes and has a purported antistress role in the brain (Lang et al. 1983; Landgraf and Neumann 2004; Bosch et al. 2005; Neumann and Slattery 2016). In response to stress, oxytocin is released both into the bloodstream via the posterior pituitary and to many extrahypothalamic brain regions including the extended amgydala, where it decreases anxiety and stress (Kasting 1988; Ebner et al. 2005; Knobloch et al. 2012; Campbell-Smith et al. 2015; Grinevich et al. 2016). Oxytocin has also been suggested as a putative treatment for addiction (Kovács et al. 1998). Exogenous oxytocin administered to animal models has been found to reduce consumption, withdrawal symptomology, and relapse associated with many drugs of abuse, including stimulants, opioids, and alcohol (Lee and Davis 1997; Kovács et al. 1998; Carson et al. 2010; Bowen et al. 2011; Bahi 2015; Baracz et al. 2016; Bowen and Neumann 2017; Cox et al. 2017; Kohtz et al. 2018). In particular, oxytocin may be an effective treatment for alcohol addiction as intranasal oxytocin administration has been found to reduce alcohol craving, consumption, and withdrawal symptoms in alcohol-dependent patients, as well as reduce neural activity in response to alcohol-related cues in heavy drinkers (Pedersen et al. 2013; Mitchell et al. 2016; Hansson et al. 2018). However, the precise mechanism by which oxytocin decreases alcohol intake and withdrawal symptoms is not yet known. In rodent models, administration of oxytocin both peripherally and directly into the central nervous system decreases alcohol consumption in nondependent animals (MacFadyen et al. 2016; King et al. 2017), and as the oxytocin receptor (OXTR) is expressed throughout the brain and peripheral systems it has not been established where oxytocin acts to affect addiction behavior. Notably, oxytocin reaches the brain following both intraperitoneal and intranasal administration in rodents (Neumann et al. 2013; Tanaka et al. 2018) and intravenous and intranasal administration in macaques (Lee et al. 2018). Additionally, intracerebroventricular oxytocin reduced cue reactivity in dependent but not nondependent rats (Hansson et al. 2018), suggesting a centrally mediated effect on alcoholdependent individuals. In collaboration with researchers at the National Institute on Alcohol Abuse and Alcoholism and the National Institute on Drug Abuse, we found that intracerebro- 
ventricular oxytocin or the non-blood barrier penetrant OXTR agonist PF-06655075 blocked the enhanced motivation and escalated alcohol drinking seen in dependent rats. In addition, peripheral administration of PF-06655075 did not decrease drinking and systemic administration of the peripherally restricted OXTR antagonist L-371,257 did not block the effects of centrally administered oxytocin (Tunstall et al. 2019). These results suggest oxytocin acts in the brain to decrease excessive alcohol drinking seen with alcohol dependence.

\section{OXYTOCIN AND SYNAPTIC TRANSMISSION IN THE CeA}

Oxytocin is primarily expressed in neurons of the PVN and supraoptic nuclei (SON) of the hypothalamus, and projections from these neurons are found in the CeA, where OXTRs are expressed on GABAergic neurons (Huber et al. 2005; Viviani et al. 2011; Stoop 2012). Some of these OXTR-expressing GABAergic neurons in the CeL project to the CeM and inhibit GABAergic output of the CeM (Huber et al. 2005). As oxytocin modulates GABAergic signaling in the $\mathrm{CeA}$, and the importance of CeA GABAergic signaling in alcohol dependence, we examined the effects of oxytocin and alcohol on synaptic transmission in the CeA (Tunstall et al. 2019).

Oxytocin inhibited evoked IPSPs in nondependent rats, and increased PPF suggesting an effect of decreasing presynaptic GABA release. In dependent rats, oxytocin had no effect on evoked IPSPs, but blocked potentiation of IPSPs by acute alcohol. Oxytocin decreased network-dependent sIPSC amplitudes in both nondependent and dependent rats, indicating some postsynaptic effects of oxytocin, but again, oxytocin blocked the acute alcohol-induced increase in presynaptic GABA release (increased sIPSC frequency) in dependent rats only (Tunstall et al. 2019). The effects of oxytocin to block alcohol-induced increases in dependent rats is not only similar between these two networkdependent forms of GABAergic transmission, but is also in agreement with oxytocin suppressing escalated alcohol intake in dependent rats. These results support the idea that oxytocin blocks alcohol-dependence-induced escalation in alcohol intake through effects on GABA transmission in the CeA (Tunstall et al. 2019).

\section{DISINHIBITION MODEL OF CeA OUTPUT}

As noted above, most neurons in the CeA are GABAergic inhibitory projection neurons or interneurons that cotransmit GABA and one or more neuropeptides. Peptides that promote anxiety-like behavior and alcohol self-administration (e.g., CRF) generally increase, whereas peptides that reduce anxiety-like behavior and alcohol self-administration (e.g., nociceptin, oxytocin) decrease GABAergic transmission in the CeA. In our slice preparation, we stimulate and record locally in the medial portion of the CeA, and recordings of GABAergic transmission reflect the activity of inhibitory interneurons or projection neurons (via collaterals) within the CeA. Therefore, increases in GABAergic transmission within the CeA following application of acute alcohol or CRF will inhibit the activity of GABAergic neurons projecting out of the CeA. Conversely, decreases in GABAergic transmission in $\mathrm{CeA}$ neurons (e.g., following nociceptin or oxytocin application) will reduce inhibition of GABAergic neurons projecting out of the $\mathrm{CeA}$, thereby facilitating release of GABA in downstream targets (e.g., BNST, periaqueductal gray). Thus, increases or decreases in inhibitory output from the $\mathrm{CeA}$ to downstream effector regions may decrease or increase anxiety-like behavior, respectively (Paré et al. 2004; Davis et al. 2010; Tye et al. 2011). Furthermore, alcohol markedly affects excitatory transmission in the CeA, particularly via NMDARs (Roberto et al. 2004b, 2006; Kallupi et al. 2014), lending at least partial buffering of alcohol effects on inhibitory transmission. Finally, alcohol may alter the release of local opioids (Lam et al. 2008; Gilpin et al. 2014), endocannabinoids (Roberto et al. 2010; Kirson et al. 2018), and/or NPY (Gilpin et al. 2008a,b; Gilpin and Roberto 2012) in CeA that in turn may increase GABA-mediated inhibition of downstream target areas. Other neuropeptides (e.g., substance P, galanin) are also likely to regulate the synaptic transmission within the CeA. 
M. Roberto et al.

\section{CONCLUSIONS}

The data summarized here support the idea that the CeA is a critical locus of neuroadaptation during the transition to alcohol dependence. Alcohol has strong and persistent effects, particularly on inhibitory transmission, in the CeA of alcohol-dependent animals. Neuropeptides present at high levels in the CeA profoundly alter inhibitory transmission, and potentially also excitatory transmission. The ability of these neuropeptides to affect neurotransmission in the CeA, either alone or in combination with alcohol, is often dysregulated in alcohol dependence. Although manipulation of many of these peptides affects alcohol drinking in alcoholdependent but not nondependent animals, it is unsurprising that these neuropeptides affect basal neurotransmission in the CeA of alcoholnaive animals, especially because these peptides, when microinjected into the CeA, modulate anxiety-related behavior independent of alcohol exposure history. This point also enhances our understanding of why these neuropeptide systems are recruited and/or up-regulated during the transition to alcohol dependence, a dynamic disease defined largely by a negative emotional state in the absence of the drug. Finally, our electrophysiological data suggest that synaptic transmission and the special neuronal circuitry in the CeA may be an important point of convergence for the neuroadaptations that occur during the transition to alcohol dependence. Our understanding of this pivotal system as a "bellwether" target for therapeutic testing for anxiety and AUDs may be reliably predicted by drug effects on synaptic transmission in the CeA. Thus, we predict that most drugs that decrease GABAergic transmission in CeA neurons will be logical candidates for treatment of anxiety and/or AUDs.

\section{ACKNOWLEDGMENTS}

This work was supported by National Institute of Alcoholism Grants Nos. AA015566, AA06420, AA017447, AA13498, AA027700, AA026638, AA021491, and AA016985. This is manuscript No. 29898 from The Scripps Research Institute.

\section{REFERENCES}

Aguayo LG, Peoples RW, Yeh HH, Yevenes GE. 2002. GABA-A receptors as molecular sites of ethanol action. Direct or indirect actions? Curr Top Med Chem 2: 869885. doi:10.2174/1568026023393426

Aguilar-Valles A, Sánchez E, de Gortari P, Balderas I, Ramírez-Amaya V, Bermúdez-Rattoni F, Joseph-Bravo P. 2005. Analysis of the stress response in rats trained in the water-maze: differential expression of corticotropin-releasing hormone, CRH-R1, glucocorticoid receptors and brain-derived neurotrophic factor in limbic regions. Neuroendocrinology 82: 306-319. doi:10.1159/ 000093129

Albrechet-Souza L, Hwa LS, Han X, Zhang EY, DeBold JF, Miczek KA. 2015. Corticotropin releasing factor binding protein and $\mathrm{CRF}_{2}$ receptors in the ventral tegmental area: modulation of ethanol binge drinking in C57BL/6J mice. Alcohol Clin Exp Res 39: 1609-1618. doi:10.1111/acer .12825

Arborelius L, Skelton KH, Thrivikraman KV, Plotsky PM, Schulz DW, Owens MJ. 2000. Chronic administration of the selective corticotropin-releasing factor 1 receptor antagonist CP-154,526: Behavioral, endocrine, and neurochemical effects in the rat. J Pharmacol Exp Ther 294: 588-597.

Ariwodola OJ, Weiner JL. 2004. Ethanol potentiation of GABAergic synaptic transmission may be self-limiting: role of presynaptic $\mathrm{GABA}_{\mathrm{B}}$ receptors. J Neurosci 24: 10679-10686. doi:10.1523/jneurosci.1768-04.2004

Augier E, Barbier E, Dulman RS, Licheri V, Augier G, Domi E, Barchiesi R, Farris S, Nätt D, Mayfield RD, et al. 2018. A molecular mechanism for choosing alcohol over an alternative reward. Science 360: 1321-1326. doi:10.1126/sci ence.aao1157

Bahi A. 2015. The oxytocin receptor impairs ethanol reward in mice. Physiol Behav 139: 321-327. doi:10.1016/j .physbeh.2014.11.046

Baiamonte BA, Valenza M, Roltsch EA, Whitaker AM, Baynes BB, Sabino V, Gilpin NW. 2014. Nicotine dependence produces hyperalgesia: role of corticotropin-releasing factor-1 receptors (CRF1Rs) in the central amygdala (CeA). Neuropharmacology 77: 217-223. doi:10.1016/j .neuropharm.2013.09.025

Bajo M, Cruz MT, Siggins GR, Messing R, Roberto M. 2008. Protein kinase $\mathrm{C} \varepsilon$ mediation of CRF- and ethanol-induced GABA release in central amygdala. Proc Natl Acad Sci 105: 8410-8415. doi:10.1073/pnas.0802302105

Baracz SJ, Everett NA, McGregor IS, Cornish JL. 2016. Oxytocin in the nucleus accumbens core reduces reinstatement of methamphetamine-seeking behaviour in rats. Addict Biol 21: 316-325. doi:10.1111/adb.12198

Behan DP, De Souza EB, Lowry PJ, Potter E, Sawchenko P, Vale WW. 1995. Corticotropin releasing factor (CRF) binding protein: a novel regulator of CRF and related peptides. Front Neuroendocrinol 16: 362-382. doi:10 $.1006 /$ frne.1995.1013

Belelli D, Harrison NL, Maguire J, Macdonald RL, Walker MC, Cope DW. 2009. Extrasynaptic $\mathrm{GABA}_{\mathrm{A}}$ receptors: form, pharmacology, and function. J Neurosci 29: 12757-12763. doi:10.1523/jneurosci.3340-09.2009 
Berton F, Francesconi WG, Madamba SG, Zieglgansberger W, Siggins GR. 1998. Acamprosate enhances $N$-methylD-apartate receptor-mediated neurotransmission but inhibits presynaptic $\mathrm{GABA}_{\mathrm{B}}$ receptors in nucleus accumbens neurons. Alcohol Clin Exp Res 22: 183-191. doi:10 $.1111 / j .1530-0277.1998 . t b 03636 . x$

Blednov YA, Harris RA. 2008. Metabotropic glutamate receptor 5 (mGluR5) regulation of ethanol sedation, dependence and consumption: relationship to acamprosate actions. Int J Neuropsychopharmacol 11: 775-793. doi:10 .1017/S1461145708008584

Bosch OJ, Meddle SL, Beiderbeck DI, Douglas AJ, Neumann ID. 2005. Brain oxytocin correlates with maternal aggression: link to anxiety. J Neurosci 25: 6807-6815. doi:10 .1523/jneurosci.1342-05.2005

Bowen MT, Neumann ID. 2017. Rebalancing the addicted brain: oxytocin interference with the neural substrates of addiction. Trends Neurosci 40: 691-708. doi:10.1016/j tins.2017.10.003

Bowen MT, Carson DS, Spiro A, Arnold JC, McGregor IS. 2011. Adolescent oxytocin exposure causes persistent reductions in anxiety and alcohol consumption and enhances sociability in rats. PLOS ONE 6: e27237. doi:10 .1371/journal.pone.0027237

Boyle AE, Segal R, Smith BR, Amit Z. 1993. Bidirectional effects of GABAergic agonists and antagonists on maintenance of voluntary ethanol intake in rats. Pharmacol Biochem Behav 46: 179-182. doi:10.1016/0091-3057(93) 90338-T

Breese GR, Overstreet DH, Knapp DJ. 2005. Conceptual framework for the etiology of alcoholism: a "kindling"| stress hypothesis. Psychopharmacology (Berl) 178: 367380. doi:10.1007/s00213-004-2016-2

Breese GR, Criswell HE, Carta M, Dodson PD, Hanchar HJ, Khisti RT, Mameli M, Ming Z, Morrow AL, Olsen RW, et al. 2006. Basis of the gabamimetic profile of ethanol. Alcohol Clin Exp Res 30: 731-744. doi:10.1111/j.0145-6008 .2006.00086.x

Brickley SG, Mody I. 2012. Extrasynaptic GABA A receptors: their function in the CNS and implications for disease. Neuron 73: 23-34. doi:10.1016/j.neuron.2011.12.012

Bruijnzeel AW, Zislis G, Wilson C, Gold MS. 2007. Antagonism of CRF receptors prevents the deficit in brain reward function associated with precipitated nicotine withdrawal in rats. Neuropsychopharmacology 32: 955963. doi:10.1038/sj.npp.1301192

Bruijnzeel AW, Prado M, Isaac S. 2009. Corticotropin-releasing factor- 1 receptor activation mediates nicotine withdrawal-induced deficit in brain reward function and stress-induced relapse. Biol Psychiatry 66: 110-117. doi:10.1016/j.biopsych.2009.01.010

Bruijnzeel AW, Small E, Pasek TM, Yamada H. 2010. Corticotropin-releasing factor mediates the dysphoria-like state associated with alcohol withdrawal in rats. Behav Brain Res 210: 288-291. doi:10.1016/j.bbr.2010.02.043

Bruijnzeel AW, Ford J, Rogers JA, Scheick S, Ji Y, Bishnoi M, Alexander JC. 2012. Blockade of CRF1 receptors in the central nucleus of the amygdala attenuates the dysphoria associated with nicotine withdrawal in rats. Pharmacol Biochem Behav 101: 62-68. doi:10.1016/j.pbb.2011.12 .001
Campbell-Smith EJ, Holmes NM, Lingawi NW, Panayi MC, Westbrook RF. 2015. Oxytocin signaling in basolateral and central amygdala nuclei differentially regulates the acquisition, expression, and extinction of context-conditioned fear in rats. Learn Mem 22: 247-257. doi:10.1101/ $\operatorname{lm} .036962 .114$

Carpenter-Hyland EP, Woodward JJ, Chandler LJ. 2004. Chronic ethanol induces synaptic but not extrasynaptic targeting of NMDA receptors. J Neurosci 24: 7859-7868. doi:10.1523/jneurosci.1902-04.2004

Carson DS, Cornish JL, Guastella AJ, Hunt GE, McGregor IS. 2010. Oxytocin decreases methamphetamine selfadministration, methamphetamine hyperactivity, and relapse to methamphetamine-seeking behaviour in rats. Neuropharmacology 58: 38-43. doi:10.1016/j.neuro pharm.2009.06.018

Cassell MD, Gray TS, Kiss JZ. 1986. Neuronal architecture in the rat central nucleus of the amygdala: a cytological, hodological, and immunocytochemical study. J Comp Neurol 246: 478-499. doi:10.1002/cne.902460406

Cebere A, Cebers G, Liljequist S. 1999. Enhancement of NMDA-induced functional responses without concomitant NMDA receptor changes following chronic ethanol exposure in cerebellar granule cells. Naunyn Schmiedebergs Arch Pharmacol 360: 623-632. doi:10.1007/ s002109900133

Chieng BC, Christie MJ, Osborne PB. 2006. Characterization of neurons in the rat central nucleus of the amygdala cellular physiology, morphology, and opioid sensitivity. J Comp Neurol 497: 910-927. doi:10.1002/cne.21025

Chu K, Koob GF, Cole M, Zorrilla EP, Roberts AJ. 2007. Dependence-induced increases in ethanol self-administration in mice are blocked by the CRF1 receptor antagonist antalarmin and by CRF1 receptor knockout. Pharmacol Biochem Behav 86: 813-821. doi:10.1016/j.pbb 2007.03.009

Ciccocioppo R, Panocka I, Polidori C, Regoli D, Massi M. 1999. Effect of nociceptin on alcohol intake in alcoholpreferring rats. Psychopharmacology (Berl) 141: 220-224. doi:10.1007/s002130050828

Ciccocioppo R, Economidou D, Fedeli A, Massi M. 2003. The nociceptin/orphanin FQ/NOP receptor system as a target for treatment of alcohol abuse: a review of recent work in alcohol-preferring rats. Physiol Behav 79: 121128. doi:10.1016/S0031-9384(03)00112-4

Ciccocioppo R, Economidou D, Fedeli A, Angeletti S, Weiss F, Heilig M, Massi M. 2004. Attenuation of ethanol self-administration and of conditioned reinstatement of alcohol-seeking behaviour by the antiopioid peptide nociceptin/orphanin FQ in alcohol-preferring rats. Psychopharmacology (Berl) 172: 170-178. doi:10.1007/ s00213-003-1645-1

Ciccocioppo R, Economidou D, Cippitelli A, Cucculelli M, Ubaldi M, Soverchia L, Lourdusamy A, Massi M. 2006. Genetically selected Marchigian Sardinian alcohol-preferring (msP) rats: an animal model to study the neurobiology of alcoholism. Addict Biol 11: 339-355. doi:10 $.1111 / \mathrm{j} .1369-1600.2006 .00032 . \mathrm{x}$

Ciccocioppo R, de Guglielmo G, Hansson AC, Ubaldi M, Kallupi M, Cruz MT, Oleata CS, Heilig M, Roberto M. 2014a. Restraint stress alters nociceptin/orphanin FQ and CRF systems in the rat central amygdala: significance for 
M. Roberto et al.

anxiety-like behaviors. J Neurosci 34: 363-372. doi:10 .1523/jneurosci.2400-13.2014

Ciccocioppo R, Stopponi S, Economidou D, Kuriyama M, Kinoshita H, Heilig M, Roberto M, Weiss F, Teshima K. 2014b. Chronic treatment with novel brain-penetrating selective NOP receptor agonist MT-7716 reduces alcohol drinking and seeking in the rat. Neuropsychopharmacology 39: 2601-2610. doi:10.1038/npp.2014.113

Ciccocioppo R, Borruto AM, Domi A, Teshima K, Cannella N, Weiss F. 2019. NOP-related mechanisms in substance use disorders. Handb Exp Pharmacol 254: 187-212. doi:10.1007/164_2019_209

Ciocchi S, Herry C, Grenier F, Wolff SB, Letzkus JJ, Vlachos I, Ehrlich I, Sprengel R, Deisseroth K, Stadler MB, et al. 2010. Encoding of conditioned fear in central amygdala inhibitory circuits. Nature 468: 277-282. doi:10.1038/na ture09559

Clarke TK, Treutlein J, Zimmermann US, Kiefer F, Skowronek MH, Rietschel M, Mann K, Schumann G. 2008. HPAaxis activity in alcoholism: examples for a gene-environment interaction. Addict Biol 13: 1-14. doi:10.1111/j $.1369-1600.2007 .00084 . x$

Cox BM, Bentzley BS, Regen-Tuero H, See RE, Reichel CM, Aston-Jones G. 2017. Oxytocin acts in nucleus accumbens to attenuate methamphetamine seeking and demand. Biol Psychiatry 81: 949-958. doi:10.1016/j.bio psych.2016.11.011

Criswell HE, Breese GR. 2005. A conceptualization of integrated actions of ethanol contributing to its GABAmimetic profile: a commentary. Neuropsychopharmacology 30: 1407-1425. doi:10.1038/sj.npp.1300750

Cruz MT, Bajo M, Maragnoli EM, Tabakoff B, Siggins GR, Roberto M. 2011. Type 7 adenylyl cyclase is involved in the ethanol and CRF sensitivity of GABAergic synapses in mouse central amygdala. Front Neurosci 4: 207.

Cruz MT, Herman MA, Kallupi M, Roberto M. 2012. Nociceptin/orphanin FQ blockade of corticotropin-releasing factor-induced $\gamma$-aminobutyric acid release in central amygdala is enhanced after chronic ethanol exposure Biol Psychiatry 71: 666-676. doi:10.1016/j.biopsych .2011 .10 .032

Davis M, Walker DL, Miles L, Grillon C. 2010. Phasic vs sustained fear in rats and humans: role of the extended amygdala in fear vs anxiety. Neuropsychopharmacology 35: 105-135. doi:10.1038/npp.2009.109

De Souza EB, Perrin MH, Insel TR, Rivier J, Vale WW Kuhar MJ. 1984. Corticotropin-releasing factor receptors in rat forebrain: autoradiographic identification. Science 224: 1449-1451. doi:10.1126/science.6328656

Dong HW, Petrovich GD, Swanson LW. 2001. Topography of projections from amygdala to bed nuclei of the stria terminalis. Brain Res Brain Res Rev 38: 192-246. doi:10 $.1016 /$ S0165-0173(01)00079-0

Dumont EC, Martina M, Samson RD, Drolet G, Paré D. 2002. Physiological properties of central amygdala neurons: species differences. Eur J Neurosci 15: 545-552. doi:10.1046/j.0953-816x.2001.01879.x

Ebner K, Bosch OJ, Krömer SA, Singewald N, Neumann ID. 2005. Release of oxytocin in the rat central amygdala modulates stress-coping behavior and the release of excitatory amino acids. Neuropsychopharmacology 30: 223230. doi:10.1038/sj.npp.1300607
Eckardt MJ, File SE, Gessa GL, Grant KA, Guerri C, Hoffman PL, Kalant H, Koob GF, Li TK, Tabakoff B. 1998. Effects of moderate alcohol consumption on the central nervous system. Alcohol Clin Exp Res 22: 998-1040. doi:10.1111/j.1530-0277.1998.tb03695.x

Economidou D, Hansson AC, Weiss F, Terasmaa A, Sommer WH, Cippitelli A, Fedeli A, Martin-Fardon R, Massi M, Ciccocioppo R, et al. 2008. Dysregulation of nociceptin/ orphanin FQ activity in the amygdala is linked to excessive alcohol drinking in the rat. Biol Psychiatry 64: 211218. doi:10.1016/j.biopsych.2008.02.004

Eiler WJ II, June HL. 2007. Blockade of $\mathrm{GABA}_{\mathrm{A}}$ receptors within the extended amygdala attenuates $\mathrm{D}_{2}$ regulation of alcohol-motivated behaviors in the ventral tegmental area of alcohol-preferring (P) rats. Neuropharmacology 52: 1570-1579. doi:10.1016/j.neuropharm.2007.03.001

Eisenhardt M, Hansson AC, Spanagel R, Bilbao A. 2015. Chronic intermittent ethanol exposure in mice leads to an up-regulation of CRH/CRHR1 signaling. Alcohol Clin Exp Res 39: 752-762. doi:10.1111/acer.12686

Fekete EM, Zorrilla EP. 2007. Physiology, pharmacology, and therapeutic relevance of urocortins in mammals: an cient CRF paralogs. Front Neuroendocrinol 28: 1-27. doi:10.1016/j.yfrne.2006.09.002

Floyd DW, Jung KY, McCool BA. 2003. Chronic ethanol ingestion facilitates $\mathrm{N}$-methyl-D-aspartate receptor function and expression in rat lateral/basolateral amygdala neurons. J Pharmacol Exp Ther 307: 1020-1029. doi:10 $.1124 /$ jpet.103.057505

Francesconi W, Berton F, Koob GF, Sanna PP. 2009. Intrinsic neuronal plasticity in the juxtacapsular nucleus of the bed nuclei of the stria terminalis (jcBNST). Prog Neuropsychopharmacol Biol Psychiatry 33: 1347-1355. doi:10 .1016/j.pnpbp.2009.08.003

Funk D, Li Z, Lê AD. 2006. Effects of environmental and pharmacological stressors on $c$-fos and corticotropinreleasing factor mRNA in rat brain: relationship to the reinstatement of alcohol seeking. Neuroscience 138: 235243. doi:10.1016/j.neuroscience.2005.10.062

Funk CK, Zorrilla EP, Lee MJ, Rice KC, Koob GF. 2007. Corticotropin-releasing factor 1 antagonists selectively reduce ethanol self-administration in ethanol-dependent rats. Biol Psychiatry 61: 78-86. doi:10.1016/j.biopsych .2006 .03 .063

Gehlert DR, Cippitelli A, Thorsell A, Le AD, Hipskind PA, Hamdouchi C, Lu J, Hembre EJ, Cramer J, Song M, et al. 2007. 3-(4-Chloro-2-morpholin-4-yl-thiazol-5-yl)-8-(1ethylpropyl)-2,6-dimethyl-imidazo [1,2-b]pyridazine: a novel brain-penetrant, orally available corticotropin-releasing factor receptor 1 antagonist with efficacy in animal models of alcoholism. J Neurosci 27: 2718-2726. doi:10.1523/jneurosci.4985-06.2007

Gilpin NW. 2012. Corticotropin-releasing factor (CRF) and neuropeptide $\mathrm{Y}(\mathrm{NPY})$ : effects on inhibitory transmission in central amygdala, and anxiety- and alcohol-related behaviors. Alcohol 46: 329-337. doi:10.1016/j.alcohol.2011 .11 .009

Gilpin NW, Roberto M. 2012. Neuropeptide modulation of central amygdala neuroplasticity is a key mediator of alcohol dependence. Neurosci Biobehav Rev 36: 873-888. doi:10.1016/j.neubiorev.2011.11.002 
The Central Amygdala and Alcohol

Gilpin NW, Stewart RB, Badia-Elder NE. 2008a. Neuropeptide $\mathrm{Y}$ administration into the amygdala suppresses ethanol drinking in alcohol-preferring $(\mathrm{P})$ rats following multiple deprivations. Pharmacol Biochem Behav 90: 470-474. doi:10.1016/j.pbb.2008.04.005

Gilpin NW, Stewart RB, Badia-Elder NE. 2008b. Neuropeptide $\mathrm{Y}$ suppresses ethanol drinking in ethanol-abstinent, but not non-ethanol-abstinent, Wistar rats. Alcohol 42: 541-551. doi:10.1016/j.alcohol.2008.07.001

Gilpin NW, Roberto M, Koob GF, Schweitzer P. 2014. Kappa opioid receptor activation decreases inhibitory transmission and antagonizes alcohol effects in rat central amyg dala. Neuropharmacology 77: 294-302. doi:10.1016/j .neuropharm.2013.10.005

Grinevich V, Knobloch-Bollmann HS, Eliava M, Busnelli M, Chini B. 2016. Assembling the puzzle: pathways of oxytocin signaling in the brain. Biol Psychiatry 79: 155-164. doi:10.1016/j.biopsych.2015.04.013

Grobin AC, Matthews DB, Devaud LL, Morrow AL. 1998. The role of $\mathrm{GABA}_{\mathrm{A}}$ receptors in the acute and chronic effects of ethanol. Psychopharmacology (Berl) 139: 2-19. doi:10.1007/s002130050685

Haass-Koffler CL, Henry AT, Melkus G, Simms JA, Naemmuddin M, Nielsen CK, Lasek AW, Magill M, Schwandt ML, Momenan R, et al. 2016. Defining the role of corticotropin releasing factor binding protein in alcohol consumption. Transl Psychiatry 6: e953. doi:10.1038/tp.2016 .208

Hansson AC, Cippitelli A, Sommer WH, Fedeli A, Bjork K, Soverchia L, Terasmaa A, Massi M, Heilig M, Ciccocioppo R. 2006. Variation at the rat Crhrl locus and sensitivity to relapse into alcohol seeking induced by environmental stress. Proc Natl Acad Sci 103: 15236-15241. doi:10.1073/pnas.0604419103

Hansson AC, Koopmann A, Uhrig S, Bühler S, Domi E, Kiessling E, Ciccocioppo R, Froemke RC, Grinevich V, Kiefer F, et al. 2018. Oxytocin reduces alcohol cuereactivity in alcohol-dependent rats and humans. Neuropsychopharmacology 43: 1235-1246. doi:10.1038/npp .2017 .257

Harris RA, Trudell JR, Mihic SJ. 2008. Ethanol's molecular targets. Sci Signal 1: re7. doi:10.1126/scisignal.128re7

Haubensak W, Kunwar PS, Cai H, Ciocchi S, Wall NR, Ponnusamy R, Biag J, Dong HW, Deisseroth K, Callaway EM, et al. 2010. Genetic dissection of an amygdala microcircuit that gates conditioned fear. Nature 468: 270-276. doi:10.1038/nature09553

Heilig M, Thorsell A, Sommer WH, Hansson AC, Ramchandani VA, George DT, Hommer D, Barr CS. 2010 Translating the neuroscience of alcoholism into clinical treatments: from blocking the buzz to curing the blues. Neurosci Biobehav Rev 35: 334-344. doi:10.1016/j .neubiorev.2009.11.018

Heimer LAG. 1991. Piecing together the puzzle of basal forebrain anatomy. In The basal forebrain: anatomy to function (ed. Napier TC, Kalivas PW, Hanin I), Advances in experimental medicine and biology, Vol. 295, pp. 1-42. Plenum, New York.

Heinrichs SC, Koob GF. 2004. Corticotropin-releasing factor in brain: a role in activation, arousal, and affect regulation J Pharmacol Exp Ther 311: 427-440. doi:10.1124/jpet.103 .052092
Herman MA, Roberto M. 2016. Cell-type-specific tonic GABA signaling in the rat central amygdala is selectively altered by acute and chronic ethanol. Addict Biol 21: 7286. doi:10.1111/adb.12181

Herman MA, Contet C, Justice NJ, Vale W, Roberto M. 2013a. Novel subunit-specific tonic GABA currents and differential effects of ethanol in the central amygdala of CRF receptor-1 reporter mice. J Neurosci 33: 3284-3298. doi:10.1523/jneurosci.2490-12.2013

Herman MA, Kallupi M, Luu G, Oleata CS, Heilig M, Koob GF, Ciccocioppo R, Roberto M. 2013b. Enhanced GABAergic transmission in the central nucleus of the amygdala of genetically selected Marchigian Sardinian rats: alcohol and CRF effects. Neuropharmacology 67: 337-348. doi:10.1016/j.neuropharm.2012.11.026

Herman MA, Contet C, Roberto M. 2016. A functional switch in tonic GABA currents alters the output of central amygdala corticotropin releasing factor receptor-1 neurons following chronic ethanol exposure. J Neurosci 36: 10729-10741. doi:10.1523/jneurosci.1267-16.2016

Hines RM, Davies PA, Moss SJ, Maguire J. 2012. Functional regulation of $\mathrm{GABA}_{\mathrm{A}}$ receptors in nervous system pathologies. Curr Opin Neurobiol 22: 552-558. doi:10.1016/j .conb.2011.10.007

Hodge CW, Chappelle AM, Samson HH. 1995. GABAergic transmission in the nucleus accumbens is involved in the termination of ethanol self-administration in rats. Alcohol Clin Exp Res 19: 1486-1493. doi:10.1111/j.1530-0277 .1995.tb01012.x

Huang MM, Overstreet DH, Knapp DJ, Angel R, Wills TA, Navarro M, Rivier J, Vale W, Breese GR. 2010. Corticotropin-releasing factor (CRF) sensitization of ethanol withdrawal-induced anxiety-like behavior is brain site specific and mediated by CRF-1 receptors: relation to stress-induced sensitization. J Pharmacol Exp Ther 332: 298-307. doi:10.1124/jpet.109.159186

Huber D, Veinante P, Stoop R. 2005. Vasopressin and oxytocin excite distinct neuronal populations in the central amygdala. Science 308: 245-248. doi:10.1126/science .1105636

Hyytiä P, Koob GF. 1995. GABA receptor antagonism in the extended amygdala decreases ethanol self-administration in rats. Eur J Pharmacol 283: 151-159. doi:10.1016/ 0014-2999(95)00314-B

Iemolo A, Blasio A, St Cyr SA, Jiang F, Rice KC, Sabino V, Cottone P. 2013. CRF-CRF1 receptor system in the central and basolateral nuclei of the amygdala differentially mediates excessive eating of palatable food. Neuropsychopharmacology 38: 2456-2466. doi:10.1038/npp.2013.147

Jenck F, Moreau JL, Martin JR, Kilpatrick GJ, Reinscheid RK, Monsma FJ Jr, Nothacker HP, Civelli O. 1997. Orphanin FQ acts as an anxiolytic to attenuate behavioral responses to stress. Proc Natl Acad Sci 94: 14854-14858. doi:10 $.1073 /$ pnas. 94.26 .14854

Jenck F, Ouagazzal AM, Pauly-Evers M, Moreau JL. 2000. OrphaninFQ: role in behavioral fear responses and vulnerability to stress? Mol Psychiatry 5: 572-574. doi:10 $.1038 /$ sj.mp.4000793

Ji G, Fu Y, Adwanikar H, Neugebauer V. 2013. Non-painrelated CRF1 activation in the amygdala facilitates synaptic transmission and pain responses. Mol Pain 9: 2. 
M. Roberto et al.

Jimenez VA, Herman MA, Cuzon Carlson VC, Walter NA, Grant KA, Roberto M. 2019. Synaptic adaptations in the central amygdala and hypothalamic paraventricular nucleus associated with protracted ethanol abstinence in male rhesus monkeys. Neuropsychopharmacology 44: 982-993. doi:10.1038/s41386-018-0290-7

Justice NJ, Yuan ZF, Sawchenko PE, Vale W. 2008. Type 1 corticotropin-releasing factor receptor expression reported in BAC transgenic mice: implications for reconciling ligand-receptor mismatch in the central corticotropin-releasing factor system. J Comp Neurol 51 1: 479-496. doi:10 $.1002 / \mathrm{cne} .21848$

Kallupi M, Varodayan FP, Oleata CS, Correia D, Luu G, Roberto M. 2014. Nociceptin/orphanin FQ decreases glutamate transmission and blocks ethanol-induced effects in the central amygdala of naive and ethanol-dependent rats. Neuropsychopharmacology 39: 1081-1092. doi:10 $.1038 /$ npp. 2013.308

Kallupi M, Scuppa G, de Guglielmo G, Calò G, Weiss F, Statnick MA, Rorick-Kehn LM, Ciccocioppo R. 2017. Genetic deletion of the nociceptin/orphanin FQ receptor in the rat confers resilience to the development of drug addiction. Neuropsychopharmacology 42: 695-706. doi:10 .1038/npp.2016.171

Karanikas CA, Lu YL, Richardson HN. 2013. Adolescent drinking targets corticotropin-releasing factor peptidelabeled cells in the central amygdala of male and female rats. Neuroscience 249: 98-105. doi:10.1016/j .neuroscience.2013.04.024

Kash TL, Winder DG. 2006. Neuropeptide Y and corticotropin-releasing factor bi-directionally modulate inhibitory synaptic transmission in the bed nucleus of the stria terminalis. Neuropharmacology 51: 1013-1022. doi:10 .1016/j.neuropharm.2006.06.011

Kash TL, Baucum AJ 2nd, Conrad KL, Colbran RJ, Winder DG. 2009. Alcohol exposure alters NMDAR function in the bed nucleus of the stria terminalis. Neuropsychopharmacology 34: 2420-2429. doi:10.1038/npp.2009.69

Kasting NW. 1988. Simultaneous and independent release of vasopressin and oxytocin in the rat. Can J Physiol Pharmacol 66: 22-26. doi:10.1139/y88-004

Ketchesin KD, Stinnett GS, Seasholtz AF. 2016. Binge drinking decreases corticotropin-releasing factor-binding protein expression in the medial prefrontal cortex of mice. Alcohol Clin Exp Res 40: 1641-1650. doi:10.1111/acer .13119

Kiefer F, Wiedemann K. 2004. Neuroendocrine pathways of addictive behaviour. Addict Biol 9: 205-212. doi:10.1111/j .1369-1600.2004.tb00534.x

King CE, Griffin WC, Luderman LN, Kates MM, McGinty JF, Becker HC. 2017. Oxytocin reduces ethanol selfadministration in mice. Alcohol Clin Exp Res 41: 955964. doi:10.1111/acer.13359

Kirson D, Oleata CS, Parsons LH, Ciccocioppo R, Roberto M. 2018. $\mathrm{CB}_{1}$ and ethanol effects on glutamatergic transmission in the central amygdala of male and female msP and Wistar rats. Addict Biol 23: 676-688. doi:10.1111/adb .12525

Kliethermes CL. 2005. Anxiety-like behaviors following chronic ethanol exposure. Neurosci Biobehav Rev 28: 837-850. doi:10.1016/j.neubiorev.2004.11.001
Knobloch HS, Charlet A, Hoffmann LC, Eliava M, Khrulev S, Cetin AH, Osten P, Schwarz MK, Seeburg PH, Stoop R, et al. 2012. Evoked axonal oxytocin release in the central amygdala attenuates fear response. Neuron 73: 553-566. doi:10.1016/j.neuron.2011.11.030

Kohtz AS, Lin B, Smith ME, Aston-Jones G. 2018. Attenuated cocaine-seeking after oxytocin administration in male and female rats. Psychopharmacology (Berl) 235: 2051-2063. doi:10.1007/s00213-018-4902-z

Koob GF. 2003. Alcoholism: allostasis and beyond. Alcohol Clin Exp Res 27: 232-243. doi:10.1097/01.ALC.000 0057122.36127.C2

Koob GF. 2008. A role for brain stress systems in addiction. Neuron 59: 11-34. doi:10.1016/j.neuron.2008.06.012

Koob GF. 2016. Corticotropin-releasing factor from rodents to primates: translational hope expresses itself, pun intended. Biol Psychiatry 80: 340-342. doi:10.1016/j.bio psych.2016.06.015

Koob GF, Heinrichs SC. 1999. A role for corticotropin releasing factor and urocortin in behavioral responses to stressors. Brain Res 848: 141-152. doi:10.1016/S00068993(99)01991-5

Koob GF, Mason BJ. 2016. Existing and future drugs for the treatment of the dark side of addiction. Annu Rev Pharmacol Toxicol 56: 299-322. doi:10.1146/annurev-pharm tox-010715-103143

Koob GF, Simon EJ. 2009. The neurobiology of addiction: where we have been and where we are going. J Drug Issues 39: 115-132. doi:10.1177/002204260903900110

Koob GF, Volkow ND. 2016. Neurobiology of addiction: a neurocircuitry analysis. Lancet Psychiatry 3: 760-773. doi:10.1016/S2215-0366(16)00104-8

Koob GF, Zorrilla EP. 2010. Neurobiological mechanisms of addiction: focus on corticotropin-releasing factor. Curr Opin Investig Drugs 11: 63-71.

Koster A, Montkowski A, Schulz S, Stube EM, Knaudt K, Jenck F, Moreau JL, Nothacker HP, Civelli O, Reinscheid RK. 1999. Targeted disruption of the orphanin FQ/nociceptin gene increases stress susceptibility and impairs stress adaptation in mice. Proc Natl Acad Sci 96: 1044410449. doi:10.1073/pnas.96.18.10444

Kovács GL, Sarnyai Z, Szabó G. 1998. Oxytocin and addiction: a review. Psychoneuroendocrinology 23: 945-962. doi:10.1016/S0306-4530(98)00064-X

Krettek JE, Price JL. 1978. Amygdaloid projections to subcortical structures within the basal forebrain and brainstem in the rat and cat. J Comp Neurol 178: 225-253. doi:10.1002/cne.901780204

Kufahl PR, Martin-Fardon R, Weiss F. 2011. Enhanced sensitivity to attenuation of conditioned reinstatement by the mGluR 2/3 agonist LY379268 and increased functional activity of mGluR $2 / 3$ in rats with a history of ethanol dependence. Neuropsychopharmacology 36: 2762-2773. doi:10.1038/npp.2011.174

Kumar S, Fleming RL, Morrow AL. 2004. Ethanol regulation of $\gamma$-aminobutyric acid A receptors: genomic and nongenomic mechanisms. Pharmacol Ther 101: 211-226. doi:10.1016/j.pharmthera.2003.12.001

Kumar S, Porcu P, Werner DF, Matthews DB, Diaz-Granados JL, Helfand RS, Morrow AL. 2009. The role of $\mathrm{GABA}_{\mathrm{A}}$ receptors in the acute and chronic effects of eth- 
anol: a decade of progress. Psychopharmacology (Berl) 205: 529-564. doi:10.1007/s00213-009-1562-z

Kuzmin A, Sandin J, Terenius L, Ögren SO. 2003. Acquisition, expression, and reinstatement of ethanol-induced conditioned place preference in mice: effects of opioid receptor-like 1 receptor agonists and naloxone. J Pharmacol Exp Ther 304: 310-318. doi:10.1124/jpet.102.041350

Kuzmin A, Kreek MJ, Bakalkin G, Liljequist S. 2007. The nociceptin/orphanin FQ receptor agonist Ro 64-6198 reduces alcohol self-administration and prevents relapselike alcohol drinking. Neuropsychopharmacology 32: 902-910. doi:10.1038/sj.npp.1301169

Läck AK, Floyd DW, McCool BA. 2005. Chronic ethanol ingestion modulates proanxiety factors expressed in rat central amygdala. Alcohol 36: 83-90. doi:10.1016/j .alcohol.2005.07.004

Läck AK, Diaz MR, Chappell A, DuBois DW, McCool BA. 2007. Chronic ethanol and withdrawal differentially modulate pre- and postsynaptic function at glutamatergic synapses in rat basolateral amygdala. J Neurophysiol 98: 3185-3196. doi:10.1152/jn.00189.2007

Lam MP, Marinelli PW, Bai L, Gianoulakis C. 2008. Effects of acute ethanol on opioid peptide release in the central amygdala: an in vivo microdialysis study. Psychopharmacology (Berl) 201: 261-271. doi:10.1007/s00213-0081267-8

Landgraf R, Neumann ID. 2004. Vasopressin and oxytocin release within the brain: a dynamic concept of multiple and variable modes of neuropeptide communication. Front Neuroendocrinol 25: 150-176. doi:10.1016/j.yfrne .2004.05.001

Lang RE, Heil JW, Ganten D, Hermann K, Unger T, Rascher W. 1983. Oxytocin unlike vasopressin is a stress hormone in the rat. Neuroendocrinology 37: 314-316. doi:10.1159/ 000123566

Lee Y, Davis M. 1997. Role of the hippocampus, the bed nucleus of the stria terminalis, and the amygdala in the excitatory effect of corticotropin-releasing hormone on the acoustic startle reflex. J Neurosci 17: 6434-6446. doi:10.1523/jneurosci.17-16-06434.1997

Lee Y, Fitz S, Johnson PL, Shekhar A. 2008. Repeated stimulation of CRF receptors in the BNST of rats selectively induces social but not panic-like anxiety. Neuropsychopharmacology 33: 2586-2594. doi:10.1038/sj.npp .1301674

Lee C, Mayfield RD, Harris RA. 2014. Altered $\gamma$-aminobutyric acid type $B$ receptor subunit 1 splicing in alcoholics. Biol Psychiatry 75: 765-773. doi:10.1016/j.biopsych.2013 .08 .028

Lee MR, Scheidweiler KB, Diao XX, Akhlaghi F, Cummins A, Huestis MA, Leggio L, Averbeck BB. 2018. Oxytocin by intranasal and intravenous routes reaches the cerebrospinal fluid in rhesus macaques: determination using a novel oxytocin assay. Mol Psychiatry 23: 115-122. doi:10.1038/ mp.2017.27

Levran O, Peles E, Randesi M, Li Y, Rotrosen J, Ott J, Adelson M, Kreek MJ. 2014a. Stress-related genes and heroin addiction: a role for a functional FKBP5 haplotype. Psychoneuroendocrinology 45: 67-76. doi:10.1016/j.psyneuen .2014 .03 .017

Levran O, Randesi M, Li Y, Rotrosen J, Ott J, Adelson M, Kreek MJ. 2014b. Drug addiction and stress-response genetic variability: association study in African Americans. Ann Hum Genet 78: 290-298. doi:10.1111/ahg .12064

Littleton JM. 2007. Acamprosate in alcohol dependence: implications of a unique mechanism of action. J Addict Med 1: 115-125. doi:10.1097/ADM.0b013e318156c26f

Lovinger DM, Homanics GE. 2007. Tonic for what ails us? High-affinity $\mathrm{GABA}_{\mathrm{A}}$ receptors and alcohol. Alcohol 41: 139-143. doi:10.1016/j.alcohol.2007.03.008

Lovinger DM, Roberto M. 2013. Synaptic effects induced by alcohol. Curr Top Behav Neurosci 13: 31-86. doi:10.1007/ 978-3-642-28720-6_143

Lowery EG, Sparrow AM, Breese GR, Knapp DJ, Thiele TE. 2008. The CRF-1 receptor antagonist, CP-154,526, attenuates stress-induced increases in ethanol consumption by BALB/cJ mice. Alcohol Clin Exp Res 32: 240-248. doi:10 $.1111 / \mathrm{j} .1530-0277.2007 .00573 . \mathrm{x}$

Lowery-Gionta EG, Navarro M, Li C, Pleil KE, Rinker JA, Cox BR, Sprow GM, Kash TL, Thiele TE. 2012. Corticotropin releasing factor signaling in the central amygdala is recruited during binge-like ethanol consumption in C57BL/6J mice. J Neurosci 32: 3405-3413. doi:10.1523/ jneurosci.6256-11.2012

MacFadyen K, Loveless R, DeLucca B, Wardley K, Deogan S, Thomas C, Peris J. 2016. Peripheral oxytocin administration reduces ethanol consumption in rats. Pharmacol Biochem Behav 140: 27-32. doi:10.1016/j.pbb.2015.10.014

Mann K, Kiefer F, Spanagel R, Littleton J. 2008. Acamprosate: recent findings and future research directions. Alcohol Clin Exp Res 32: 1105-1110. doi:10.1111/j.1530-0277 .2008.00690.x

Marinelli PW, Funk D, Juzytsch W, Harding S, Rice KC Shaham Y, Lê AD. 2007. The CRF1 receptor antagonist antalarmin attenuates yohimbine-induced increases in operant alcohol self-administration and reinstatement of alcohol seeking in rats. Psychopharmacology (Berl) 195: 345-355. doi:10.1007/s00213-007-0905-x

Martin-Fardon R, Ciccocioppo R, Massi M, Weiss F. 2000 Nociceptin prevents stress-induced ethanol-but not cocaine-seeking behavior in rats. Neuroreport 11: 19391943. doi:10.1097/00001756-200006260-00026

McCown TJ, Frye GD, Breese GR. 1985. Evidence for site specific ethanol actions in the CNS. Alcohol Drug Res 6: 423-429.

McCullough KM, Choi D, Guo J, Zimmerman K, Walton J, Rainnie DG, Ressler KJ. 2016. Molecular characterization of Thyl expressing fear-inhibiting neurons within the basolateral amygdala. Nat Commun 7: 13149. doi:10 $.1038 /$ ncomms 13149

McDonald AJ. 1982. Cytoarchitecture of the central amygdaloid nucleus of the rat. J Comp Neurol 208: 401-418. doi:10.1002/cne.902080409

Menzaghi F, Rassnick S, Heinrichs S, Baldwin H, Pich EM, Weiss F, Koob GF. 1994. The role of corticotropin-releasing factor in the anxiogenic effects of ethanol withdrawal. Ann NY Acad Sci 739: 176-184. doi:10.1111/j.1749-6632 .1994.tb19819.x

Merlo Pich E, Lorang M, Yeganeh M, Rodriguez de Fonseca F, Raber J, Koob GF, Weiss F. 1995. Increase of extracellular corticotropin-releasing factor-like immunoreactivity levels in the amygdala of awake rats during restraint stress and ethanol withdrawal as measured by microdial- 
M. Roberto et al.

ysis. J Neurosci 15: 5439-5447. doi:10.1523/jneurosci.1508-05439.1995

Meunier JC. 1997. Nociceptin/orphanin FQ and the opioid receptor-like ORL1 receptor. Eur J Pharmacol 340: 1-15. doi:10.1016/S0014-2999(97)01411-8

Meunier JC, Mollereau C, Toll L, Suaudeau C, Moisand C, Alvinerie P, Butour JL, Guillemot JC, Ferrara P, Monsarrat B, et al. 1995. Isolation and structure of the endogenous agonist of opioid receptor-like ORL1 receptor. Nature 377: 532-535. doi:10.1038/377532a0

Mitchell JM, Arcuni PA, Weinstein D, Woolley JD. 2016. Intranasal oxytocin selectively modulates social perception, craving, and approach behavior in subjects with alcohol use disorder. J Addict Med 10: 182-189. doi:10 .1097/ADM.0000000000000213

Molander A, Vengeliene V, Heilig M, Wurst W, Deussing JM, Spanagel R. 2012. Brain-specific inactivation of the Crhrl gene inhibits post-dependent and stress-induced alcohol intake, but does not affect relapse-like drinking. Neuropsychopharmacology 37: 1047-1056. doi:10.1038/ npp.2011.297

Morrow AL, Herbert JS, Montpied P. 1992. Differential effects of chronic ethanol administration on $\mathrm{GABA}_{\mathrm{A}}$ receptor $\alpha 1$ and $\alpha 6$ subunit mRNA levels in rat cerebellum. Mol Cell Neurosci 3: 251-258. doi:10.1016/1044-7431(92) 90045-4

Müller MB, Zimmermann S, Sillaber I, Hagemeyer TP Deussing JM, Timpl P, Kormann MS, Droste SK, Kühn R, Reul JM, et al. 2003. Limbic corticotropin-releasing hormone receptor 1 mediates anxiety-related behavior and hormonal adaptation to stress. Nat Neurosci 6: 1100-1107. doi:10.1038/nn1123

Neal CR Jr, Mansour A, Reinscheid R, Nothacker HP, Civelli O, Watson SJ Jr. 1999. Localization of orphanin FQ (nociceptin) peptide and messenger RNA in the central nervous system of the rat. J Comp Neurol 406: 503-547. doi:10.1002/(SICI)1096-9861(19990419)406:4<503::AIDCNE7>3.0.CO;2-P

Neumann ID, Slattery DA. 2016. Oxytocin in general anxiety and social fear: a translational approach. Biol Psychiatry 79: 213-221. doi:10.1016/j.biopsych.2015.06.004

Neumann ID, Maloumby R, Beiderbeck DI, Lukas M, Landgraf R. 2013. Increased brain and plasma oxytocin after nasal and peripheral administration in rats and mice. Psychoneuroendocrinology 38: 1985-1993. doi:10.1016/j .psyneuen.2013.03.003

Nie Z, Madamba SG, Siggins GR. 2000. Ethanol enhances $\gamma$ aminobutyric acid responses in a subpopulation of nucleus accumbens neurons: role of metabotropic glutamate receptors. J Pharmacol Exp Ther 293: 654-661.

Nie Z, Schweitzer P, Roberts AJ, Madamba SG, Moore SD, Siggins GR. 2004. Ethanol augments GABAergic transmission in the central amygdala via CRF1 receptors. Science 303: 1512-1514. doi:10.1126/science. 1092550

Nie Z, Zorrilla EP, Madamba SG, Rice KC, Roberto M, Siggins GR. 2009. Presynaptic CRF1 receptors mediate the ethanol enhancement of GABAergic transmission in the mouse central amygdala. ScientificWorldJournal 9: 6885. doi:10.1100/tsw.2009.1

Obara I, Bell RL, Goulding SP, Reyes CM, Larson LA, Ary AW, Truitt WA, Szumlinski KK. 2009. Differential effect of chronic ethanol consumption and withdrawal on homer/glutamate receptor expression in subregions of the accumbens and amygdala of P rats. Alcohol Clin Exp Res 33: 1924-1934. doi:10.1111/j.1530-0277.2009.01030 . $\mathrm{x}$

Olive MF, Koenig HN, Nannini MA, Hodge CW. 2002. Elevated extracellular CRF levels in the bed nucleus of the stria terminalis during ethanol withdrawal and reduction by subsequent ethanol intake. Pharmacol Biochem Behav 72: 213-220. doi:10.1016/S0091-3057(01)00748-1

Ouagazzal AM, Moreau JL, Pauly-Evers M, Jenck F. 2003. Impact of environmental housing conditions on the emotional responses of mice deficient for nociceptin/orphanin FQ peptide precursor gene. Behav Brain Res 144: 111-117. doi:10.1016/S0166-4328(03)00066-4

Papadeas S, Grobin AC, Morrow AL. 2001. Chronic ethanol consumption differentially alters $\mathrm{GABA}_{\mathrm{A}}$ receptor alphal and alpha4 subunit peptide expression and $\mathrm{GABA}_{\mathrm{A}}$ receptor-mediated $36 \mathrm{Cl}^{-}$uptake in mesocorticolimbic regions of rat brain. Alcohol Clin Exp Res 25: 1270-1275.

Paré D, Quirk GJ, Ledoux JE. 2004. New vistas on amygdala networks in conditioned fear. J Neurophysiol 92: 1-9. doi:10.1152/jn.00153.2004

Pastor R, Reed C, Burkhart-Kasch S, Li N, Sharpe AL, Coste SC, Stenzel-Poore MP, Phillips TJ. 2011. Ethanol concentration-dependent effects and the role of stress on ethanol drinking in corticotropin-releasing factor type 1 and double type 1 and 2 receptor knockout mice. Psychophar macology (Berl) 218: 169-177. doi:10.1007/s00213-0112284-6

Pedersen CA, Smedley KL, Leserman J, Jarskog LF, Rau SW, Kampov-Polevoi A, Casey RL, Fender T, Garbutt JC. 2013. Intranasal oxytocin blocks alcohol withdrawal in human subjects. Alcohol Clin Exp Res 37: 484-489. doi:10.1111/j.1530-0277.2012.01958.x

Pelleymounter MA, Joppa M, Carmouche M, Cullen MJ, Brown B, Murphy B, Grigoriadis DE, Ling N, Foster AC. 2000. Role of corticotropin-releasing factor (CRF) receptors in the anorexic syndrome induced by CRF. $J$ Pharmacol Exp Ther 293: 799-806.

Penzo MA, Robert V, Li B. 2014. Fear conditioning potentiates synaptic transmission onto long-range projection neurons in the lateral subdivision of central amygdala. $J$ Neurosci 34: 2432-2437. doi:10.1523/jneurosci.4166-13 .2014

Petrovich GD, Risold PY, Swanson LW. 1996. Organization of projections from the basomedial nucleus of the amygdala: a PHAL study in the rat. J Comp Neurol 374: 387420. doi:10.1002/(SICI)1096-9861(19961021)374:3<387: :AID-CNE6>3.0.CO;2-Y

Phelps EA, LeDoux JE. 2005. Contributions of the amygdala to emotion processing: from animal models to human behavior. Neuron 48: 175-187. doi:10.1016/j.neuron .2005.09.025

Pitkänen A, Amaral DG. 1994. The distribution of GABAergic cells, fibers, and terminals in the monkey amygdaloid complex: an immunohistochemical and in situ hybridization study. J Neurosci 14: 2200-2224. doi:10 .1523/jneurosci.14-04-02200.1994

Pitkänen A, Pikkarainen M, Nurminen N, Ylinen A. 2000. Reciprocal connections between the amygdala and the hippocampal formation, perirhinal cortex, and postrhinal 
cortex in rat. A review. Ann NY Acad Sci 911: 369-391. doi:10.1111/j.1749-6632.2000.tb06738.x

Pomrenze MB, Millan EZ, Hopf FW, Keiflin R, Maiya R, Blasio A, Dadgar J, Kharazia V, De Guglielmo G, Crawford $\mathrm{E}$, et al. 2015. A transgenic rat for investigating the anatomy and function of corticotrophin releasing factor circuits. Front Neurosci 9: 487. doi:10.3389/fnins.2015 .00487

Post A, Smart TS, Jackson K, Mann J, Mohs R, Rorick-Kehn L, Statnick M, Anton R, O’Malley SS, Wong CJ. 2016. Proof-of-concept study to assess the nociceptin receptor antagonist LY2940094 as a new treatment for alcohol dependence. Alcohol Clin Exp Res 40: 1935-1944. doi:10.1111/acer.13147

Potter E, Behan DP, Linton EA, Lowry PJ, Sawchenko PE, Vale WW. 1992. The central distribution of a corticotropin-releasing factor (CRF)-binding protein predicts multiple sites and modes of interaction with CRF. Proc Natl Acad Sci 89: 4192-4196. doi:10.1073/pnas.89.9.4192

Pulvirenti L, Diana M. 2001. Drug dependence as a disorder of neural plasticity: focus on dopamine and glutamate. Rev Neurosci 12: 141-158. doi:10.1515/REVNEURO .2001.12.2.141

Quadros IM, Macedo GC, Domingues LP, Favoretto CA. 2016. An update on CRF mechanisms underlying alcohol use disorders and dependence. Front Endocrinol (Lausanne) 7: 134. doi:10.3389/fendo.2016.00134

Quirk GJ, Mueller D. 2008. Neural mechanisms of extinction learning and retrieval. Neuropsychopharmacology 33: 5672. doi:10.1038/sj.npp.1301555

Rainnie DG, Bergeron R, Sajdyk TJ, Patil M, Gehlert DR, Shekhar A. 2004. Corticotrophin releasing factor-induced synaptic plasticity in the amygdala translates stress into emotional disorders. J Neurosci 24: 3471-3479. doi:10 .1523 /jneurosci.5740-03.2004

Rassnick S, Heinrichs SC, Britton KT, Koob GF. 1993. Microinjection of a corticotropin-releasing factor antagonist into the central nucleus of the amygdala reverses anxiogenic-like effects of ethanol withdrawal. Brain Res 605: 25-32. doi:10.1016/0006-8993(93)91352-S

Reinscheid RK, Nothacker HP, Bourson A, Ardati A, Henningsen RA, Bunzow JR, Grandy DK, Langen H, Monsma FJ Jr, Civelli O. 1995. Orphanin FQ: a neuropeptide that activates an opioidlike G protein- coupled receptor. Science 270: 792-794. doi:10.1126/science.270.5237.792

Roberto M, Siggins GR. 2006. Nociceptin/orphanin FQ presynaptically decreases GABAergic transmission and blocks the ethanol-induced increase of GABA release in central amygdala. Proc Natl Acad Sci 103: 9715-9720. doi:10.1073/pnas.0601899103

Roberto M, Madamba SG, Moore SD, Tallent MK, Siggins GR. 2003. Ethanol increases GABAergic transmission at both pre- and postsynaptic sites in rat central amygdala neurons. Proc Natl Acad Sci 100: 2053-2058. doi:10.1073/ pnas. 0437926100

Roberto M, Madamba SG, Stouffer DG, Parsons L, Siggins GR. 2004a. Increased GABA release in the central amygdala of ethanol dependent rats. J Neurosci 24: 1015910166. doi:10.1523/jneurosci.3004-04.2004

Roberto M, Schweitzer P, Madamba SG, Stouffer DG, Parsons LH, Siggins GR. 2004b. Acute and chronic ethanol alter glutamatergic transmission in rat central amygdala: an in vitro and in vivo analysis. J Neurosci 24: 1594-1603. doi:10.1523/jneurosci.5077-03.2004

Roberto M, Schweitzer P, Madamba SG, Nie Z, Siggins GR. 2005. Ethanol-CRF interactions at GABAergic synapses in rat central amygdala. Alcohol Clin Exp Res Suppl 29: 26.

Roberto M, Bajo M, Crawford E, Madamba SG, Siggins GR. 2006. Chronic ethanol exposure and protracted abstinence alter NMDA receptors in central amygdala. $\mathrm{Neu}$ ropsychopharmacology 31: 988-996. doi:10.1038/sj.npp .1300840

Roberto M, Gilpin NW, O'Dell LE, Cruz MT, Morse AC, Siggins GR, Koob GF. 2008. Cellular and behavioral interactions of gabapentin with alcohol dependence. J Neurosci 28: 5762-5771. doi:10.1523/jneurosci.0575-08.2008

Roberto M, Cruz MT, Gilpin NW, Sabino V, Schweitzer P, Bajo M, Cottone P, Madamba SG, Stouffer DG, Zorrilla EP, et al. 2010. Corticotropin releasing factor-induced amygdala $\gamma$-aminobutyric acid release plays a key role in alcohol dependence. Biol Psychiatry 67: 831-839. doi:10 $.1016 /$ j.biopsych.2009.11.007

Roberto M, Gilpin NW, Siggins GR. 2012. The central amygdala and alcohol: role of $\gamma$-aminobutyric acid, glutamate, and neuropeptides. Cold Spring Harb Perspect Med 2: a012195. doi:10.1101/cshperspect.a012195

Roberto M, Spierling SR, Kirson D, Zorrilla EP. 2017. Corticotropin-releasing factor (CRF) and addictive behaviors. Int Rev Neurobiol 136: 5-51. doi:10.1016/bs.irn .2017 .06 .004

Roberts AJ, Cole M, Koob GF. 1996. Intra-amygdala muscimol decreases operant ethanol self-administration in dependent rats. Alcohol Clin Exp Res 20: 1289-1298. doi:10 .1111/j.1530-0277.1996.tb01125.x

Rorick-Kehn LM, Ciccocioppo R, Wong CJ, Witkin JM, Martinez-Grau MA, Stopponi S, Adams BL, Katner JS, Perry KW, Toledo MA, et al. 2016. A novel, orally bioavailable nociceptin receptor antagonist, LY2940094, reduces ethanol self-administration and ethanol seeking in animal models. Alcohol Clin Exp Res 40: 945-954. doi:10 $.1111 /$ acer. 13052

Sajdyk TJ, Vandergriff MG, Gehlert DR. 1999. Amygdalar neuropeptide Y Y1 receptors mediate the anxiolytic-like actions of neuropeptide $\mathrm{Y}$ in the social interaction test. Eur J Pharmacol 368: 143-147. doi:10.1016/S0014-2999 (99)00018-7

Sakanaka M, Shibasaki T, Lederis K. 1986. Distribution and efferent projections of corticotropin-releasing factor-like immunoreactivity in the rat amygdaloid complex. Brain Res 382: 213-238. doi:10.1016/0006-8993(86)91332-6

Sanchis-Segura C, Borchardt T, Vengeliene V, Zghoul T, Bachteler D, Gass P, Sprengel R, Spanagel R. 2006. Involvement of the AMPA receptor GluR-C subunit in alcohol-seeking behavior and relapse. J Neurosci 26: 1231-1238. doi:10.1523/jneurosci.4237-05.2006

Sauguet L, Howard RJ, Malherbe L, Lee US, Corringer PJ, Harris RA, Delarue M. 2013. Structural basis for potentiation by alcohols and anaesthetics in a ligand-gated ion channel. Nat Commun 4: 1697. doi:10.1038/ncomms 2682

Semyanov A, Walker MC, Kullmann DM, Silver RA. 2004. Tonically active $\mathrm{GABA}_{\mathrm{A}}$ receptors: modulating gain and maintaining the tone. Trends Neurosci 27: 262-269. doi:10.1016/j.tins.2004.03.005 
M. Roberto et al.

Shimada S, Inagaki S, Kubota Y, Ogawa N, Shibasaki T, Takagi H. 1989. Coexistence of peptides (corticotropin releasing factor/neurotensin and substance $\mathrm{P} /$ somatostatin) in the bed nucleus of the stria terminalis and central amygdaloid nucleus of the rat. Neuroscience 30: 377-383. doi:10.1016/0306-4522(89)90259-5

Siggins GR, Roberto M, Nie Z. 2005. The tipsy terminal: presynaptic effects of ethanol. Pharmacol Ther 107: 8098. doi:10.1016/j.pharmthera.2005.01.006

Sills GJ. 2006. The mechanisms of action of gabapentin and pregabalin. Curr Opin Pharmacol 6: 108-113. doi:10 .1016/j.coph.2005.11.003

Sommer WH, Rimondini R, Hansson AC, Hipskind PA, Gehlert DR, Barr CS, Heilig MA. 2008. Upregulation of voluntary alcohol intake, behavioral sensitivity to stress, and amygdala crhr1 expression following a history of dependence. Biol Psychiatry 63: 139-145. doi:10.1016/j .biopsych.2007.01.010

Spina M, Merlo-Pich E, Chan RK, Basso AM, Rivier J, Vale W, Koob GF. 1996. Appetite-suppressing effects of urocortin, a CRF-related neuropeptide. Science 273: 15611564. doi:10.1126/science.273.5281.1561

Stoop R. 2012. Neuromodulation by oxytocin and vasopressin. Neuron 76: 142-159. doi:10.1016/j.neuron.2012.09 .025

Suárez J, Khom S, Alén F, Natividad LA, Varodayan FP, Patel RR, Kirson D, Arco R, Ballesta A, Bajo M, et al. 2019. Cessation of fluoxetine treatment increases alcohol seeking during relapse and dysregulates endocannabinoid and glutamatergic signaling in the central amygdala. Addict Biol 24: e12813.

Sun N, Cassell MD. 1993. Intrinsic GABAergic neurons in the rat central extended amygdala. J Comp Neurol 330: 381-404. doi:10.1002/cne.903300308

Sun N, Roberts L, Cassell MD. 1991. Rat central amygdaloid nucleus projections to the bed nucleus of the stria terminalis. Brain Res Bull 27: 651-662. doi:10.1016/0361-9230 (91) $90041-\mathrm{H}$

Tanaka A, Furubayashi T, Arai M, Inoue D, Kimura S, Kiriyama A, Kusamori K, Katsumi H, Yutani R, Sakane T, et al. 2018. Delivery of oxytocin to the brain for the treatment of autism spectrum disorder by nasal application. Mol Pharm 15: 1105-1111. doi:10.1021/acs.mol pharmaceut.7b00991

Ticku MK, Burch T. 1980. Alterations in $\gamma$-aminobutyric acid receptor sensitivity following acute and chronic ethanol treatments. J Neurochem 34: 417-423. doi:10.1111/j .1471-4159.1980.tb06612.x

Toll L, Bruchas MR, Calò G, Cox BM, Zaveri NT. 2016 Nociceptin/orphanin FQ receptor structure, signaling, ligands, functions, and interactions with opioid systems Pharmacol Rev 68: 419-457. doi:10.1124/pr.114.009209

Tunstall BJ, Kirson D, Zallar LJ, McConnell SA, Vendruscolo JCM, Ho CP, Oleata CS, Khom S, Manning M, Lee MR, et al. 2019. Oxytocin blocks enhanced motivation for alcohol in alcohol dependence and blocks alcohol effects on GABAergic transmission in the central amygdala. PLoS Biol 17: e2006421. doi:10.1371/journal.pbio .2006421

Tye KM, Prakash R, Kim SY, Fenno LE, Grosenick L, Zarabi H, Thompson KR, Gradinaru V, Ramakrishnan C, Deisseroth K. 2011. Amygdala circuitry mediating reversible and bidirectional control of anxiety. Nature 471: 358 362. doi: $10.1038 /$ nature 09820

Umhau JC, Momenan R, Schwandt ML, Singley E, Lifshitz M, Doty L, Adams LJ, Vengeliene V, Spanagel R, Zhang Y, et al. 2010. Effect of acamprosate on magnetic resonance spectroscopy measures of central glutamate in detoxified alcohol-dependent individuals: a randomized controlled experimental medicine study. Arch Gen Psychiatry 67: 1069-1077. doi:10.1001/archgenpsychiatry.2010.125

Valdez GR, Roberts AJ, Chan K, Davis H, Brennan M, Zorrilla EP, Koob GF. 2002. Increased ethanol self-administration and anxiety-like behavior during acute ethanol withdrawal and protracted abstinence: regulation by corticotropin-releasing factor. Alcohol Clin Exp Res 26: 1494-1501. doi:10.1111/j.1530-0277.2002.tb02448.x

Valdez GR, Zorrilla EP, Roberts AJ, Koob GF. 2003. Highpriority communication I antagonism of corticotropinreleasing factor attenuates the enhanced responsiveness to stress observed during protracted ethanol abstinence. $\mathrm{Al}$ cohol 29: 55-60. doi:10.1016/S0741-8329(03)00020-X

Varodayan FP, Correia D, Kirson D, Khom S, Oleata CS, Luu G, Schweitzer P, Roberto M. 2017a. CRF modulates glutamate transmission in the central amygdala of naive and ethanol-dependent rats. Neuropharmacology 125: 418428. doi:10.1016/j.neuropharm.2017.08.009

Varodayan FP, de Guglielmo G, Logrip ML, George O, Roberto M. 2017b. Alcohol dependence disrupts amygdalar L-type voltage-gated calcium channel mechanisms. $J$ Neurosci 37: 4593-4603. doi:10.1523/jneurosci.3721-16 .2017

Varodayan FP, Logrip ML, Roberto M. 2017c. P/Q-type voltage-gated calcium channels mediate the ethanol and CRF sensitivity of central amygdala GABAergic synapses. Neuropharmacology 125: 197-206. doi:10.1016/j.neu ropharm.2017.07.017

Veening JG, Swanson LW, Sawchenko PE. 1984. The organization of projections from the central nucleus of the amygdala to brainstem sites involved in central autonomic regulation: a combined retrograde transport-immunohistochemical study. Brain Res 303: 337-357. doi:10 .1016/0006-8993(84)91220-4

Veinante P, Freund-Mercier MJ. 1998. Intrinsic and extrinsic connections of the rat central extended amygdala: an in vivo electrophysiological study of the central amygdaloid nucleus. Brain Res 794: 188-198. doi:10.1016/S00068993(98)00228-5

Viviani D, Charlet A, van den Burg E, Robinet C, Hurni N, Abatis M, Magara F, Stoop R. 2011. Oxytocin selectively gates fear responses through distinct outputs from the central amygdala. Science 333: 104-107. doi:10.1126/sci ence. 1201043

Walker BM, Koob GF. 2007. The $\gamma$-aminobutyric acid-B receptor agonist baclofen attenuates responding for ethanol in ethanol-dependent rats. Alcohol Clin Exp Res 31: 11-18. doi:10.1111/j.1530-0277.2006.00259.x

Wallner M, Hanchar HJ, Olsen RW. 2014. Alcohol selectivity of $\beta 3$-containing $\mathrm{GABA}_{\mathrm{A}}$ receptors: evidence for a unique extracellular alcohol/imidazobenzodiazepine Ro15-4513 binding site at the $\alpha+\beta$-subunit interface in $\alpha \beta 3 \delta \mathrm{GABA}_{\mathrm{A}}$ receptors. Neurochem Res 39: 1118-1126. doi:10.1007/s11064-014-1243-0 
The Central Amygdala and Alcohol

Wan FJ, Berton F, Madamba SG, Francesconi W, Siggins GR 1996. Low ethanol concentrations enhance GABAergic inhibitory postsynaptic potentials in hippocampal pyramidal neurons only after block of $\mathrm{GABA}_{\mathrm{B}}$ receptors. Proc Natl Acad Sci 93: 5049-5054. doi:10.1073/pnas.93.10 .5049

Watanabe T, Nakagawa T, Yamamoto R, Maeda A, Minami M, Satoh M. 2002. Involvement of glutamate receptors within the central nucleus of the amygdala in naloxoneprecipitated morphine withdrawal-induced conditioned place aversion in rats. Jpn J Pharmacol 88: 399-406. doi:10.1254/jjp.88.399

Weiner JL, Valenzuela CF. 2006. Ethanol modulation of GABAergic transmission: the view from the slice. Pharmacol Ther 111: 533-554. doi:10.1016/j.pharmthera.2005 .11 .002

Weller KL, Smith DA. 1982. Afferent connections to the bed nucleus of the stria terminalis. Brain Res 232: 255-270. doi:10.1016/0006-8993(82)90272-4

Westphal NJ, Seasholtz AF. 2006. CRH-BP: the regulation and function of a phylogenetically conserved binding protein. Front Biosci 11: 1878-1891. doi:10.2741/1931

Wise RA, Koob GF. 2014. The development and maintenance of drug addiction. Neuropsychopharmacology 39: 254-262. doi:10.1038/npp.2013.261

Witkin JM, Statnick MA, Rorick-Kehn LM, Pintar JE, Ansonoff M, Chen Y, Tucker RC, Ciccocioppo R. 2014 The biology of nociceptin/orphanin FQ (N/OFQ) related to obesity, stress, anxiety, mood, and drug dependence. Pharmacol Ther 141: 283-299. doi:10.1016/j.pharmthera 2013.10.011

Witkin JM, Rorick-Kehn LM, Benvenga MJ, Adams BL, Gleason SD, Knitowski KM, Li X, Chaney S, Falcone JF, Smith JW, et al. 2016. Preclinical findings predicting efficacy and side-effect profile of LY2940094, an antagonist of nociceptin receptors. Pharmacol Res Perspect 4 e00275. doi:10.1002/prp2.275
Wolfe SA, Sidhu H, Patel RR, Kreifeldt M, D'Ambrosio SR, Contet C, Roberto M. 2019. Molecular, morphological, and functional characterization of corticotropin-releasing factor receptor 1-expressing neurons in the central nucleus of the amygdala. eNeuro 6: ENEURO.0087-19.2019. doi:10.1523/ENEURO.0087-19.2019

Wu LG, Saggau P. 1994. Presynaptic calcium is increased during normal synaptic transmission and paired-pulse facilitation, but not in long-term potentiation in area CA1 of hippocampus. J Neurosci 14: 645-654. doi:10 .1523/jneurosci.14-02-00645.1994

Zhao Y, Dayas CV, Aujla H, Baptista MA, Martin-Fardon R, Weiss F. 2006. Activation of group II metabotropic glutamate receptors attenuates both stress and cue-induced ethanol-seeking and modulates c-fos expression in the hippocampus and amygdala. J Neurosci 26: 9967-9974. doi:10.1523/jneurosci.2384-06.2006

Zhu PJ, Lovinger DM. 2006. Ethanol potentiates GABAergic synaptic transmission in a postsynaptic neuron/synaptic bouton preparation from basolateral amygdala. J Neurophysiol 96: 433-441. doi:10.1152/jn.01380.2005

Zorrilla EP, Koob GF. 2010. Progress in corticotropin-releasing factor-1 antagonist development. Drug Discov Today 15: 371-383. doi:10.1016/j.drudis.2010.02.011

Zorrilla EP, Valdez GR, Weiss F. 2001. Changes in levels of regional CRF-like-immunoreactivity and plasma corticosterone during protracted drug withdrawal in dependent rats. Psychopharmacology (Berl) 158: 374-381. doi:10 1007/s002130100773

Zorrilla EP, Heilig M, de Wit H, Shaham Y. 2013. Behavioral, biological, and chemical perspectives on targeting $\mathrm{CRF}_{1}$ receptor antagonists to treat alcoholism. Drug Alcohol Depend 128: 175-186. doi:10.1016/j.drugalcdep.2012.12 .017

Zorrilla EP, Logrip ML, Koob GF. 2014. Corticotropin releasing factor: a key role in the neurobiology of addiction. Front Neuroendocrinol 35: 234-244. doi:10.1016/j.yfrne .2014 .01 .001 


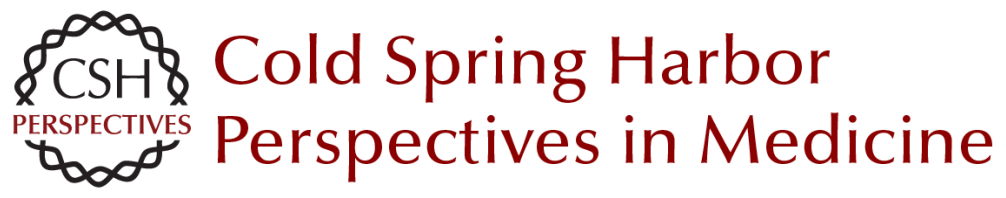

\section{The Role of the Central Amygdala in Alcohol Dependence}

Marisa Roberto, Dean Kirson and Sophia Khom

Cold Spring Harb Perspect Med 2021; doi: 10.1101/cshperspect.a039339 originally published online January 27,2020

\section{Subject Collection Addiction}

Developments from Bulk Optogenetics to Single-Cell Strategies to Dissect the Neural Circuits that Underlie Aberrant Motivational States Jose Rodriguez-Romaguera, Vijay M.K. Namboodiri, Marcus L. Basiri, et al.

Consequences of Parental Opioid Exposure on Neurophysiology, Behavior, and Health in the Next Generations

Fair M. Vassoler and Mathieu E. Wimmer

Animal Models of the Behavioral Symptoms of Substance Use Disorders Louk J.M.J. Vanderschuren and Serge H. Ahmed

Translational Research in Nicotine Addiction Miranda L. Fisher, James R. Pauly, Brett Froeliger, et al.

Neonatal Opioid Withdrawal Syndrome (NOWS): A Transgenerational Echo of the Opioid Crisis Andrew E. Weller, Richard C. Crist, Benjamin C. Reiner, et al.

Impairment of Synaptic Plasticity by Cannabis, $\Delta^{\mathbf{9}}$ -THC, and Synthetic Cannabinoids Alexander F. Hoffman, Eun-Kyung Hwang and Carl R. Lupica

Drug-Evoked Synaptic Plasticity of Excitatory Transmission in the Ventral Tegmental Area Camilla Bellone, Michael Loureiro and Christian Lüscher

Opioid-Induced Molecular and Cellular Plasticity of Ventral Tegmental Area Dopamine Neurons Marie A. Doyle and Michelle S. Mazei-Robison
The Persistent Challenge of Developing Addiction Pharmacotherapies

Sarah E. Swinford-Jackson, Charles P. O'Brien,

Paul J. Kenny, et al.

Opioid Modulation of the Gut-Brain Axis in Opioid-Associated Comorbidities

Li Zhang and Sabita Roy

Epigenetics of Drug Addiction Andrew F. Stewart, Sasha L. Fulton and lan Maze

Genetic Vulnerability to Opioid Addiction Brian Reed and Mary Jeanne Kreek

Glutamatergic Systems and Memory Mechanisms

Underlying Opioid Addiction Jasper A. Heinsbroek, Taco J. De Vries and Jamie Peters

Mechanisms of Nicotine Addiction Marina R. Picciotto and Paul J. Kenny

Neural Substrates and Circuits of Drug Addiction Matthew W. Feltenstein, Ronald E. See and Rita A. Fuchs

The Role of the Central Amygdala in Alcohol Dependence Marisa Roberto, Dean Kirson and Sophia Khom

For additional articles in this collection, see http://perspectivesinmedicine.cshlp.org/cgi/collection/ 